\title{
Geochemistry and depositional environment of the Losero Formation in the Mesa Central, México
}

\author{
María Jesús Puy-Alquiza ${ }^{1, *}$, Raúl Miranda-Aviles ${ }^{1}$, Maricela Cruz-Cruz ${ }^{1}$, Ofelia Pérez-Arbizu ${ }^{2}$, \\ Marina Vega-González², Gabriela Ana-Zanor ${ }^{3}$ \\ ${ }^{1}$ Departamento de Minas, Metalurgia y Geología, Universidad de Guanajuato, Guanajuato, México. \\ ${ }^{2}$ Universidad Nacional Autónoma de México (UNAM), Campus Juriquilla-Queretaro, Queretaro, México. \\ ${ }^{3}$ División de Ciencias de la Vida, Universidad de Guanajuato, Irapuato, Guanajuato. \\ *yosune@ugto.mx
}

\begin{abstract}
The Losero Formation is exposed in the Guanajuato Mining District, conformably overlying the Guanajuato conglomerate. Most of the up-to-date studies of the Losero Formation have indicated that this formation corresponds to a Cenozoic volcanic sequence. However, sedimentological, petrographic and geochemical evidence that supports a sedimentary or volcanic origin has not been discussed extensively. We present a comprehensive geological analysis which includes collection of samples and elaboration of eight stratigraphic columns, followed by laboratory studies including petrography, trace element determinations using Inductively Coupled Plasma Mass Spectrometry (ICP-MS) and mineralogy by X-ray diffraction and Scanning Electron Microscopy (SEM). The petrographic analysis revealed that the Losero Formation is constituted by litharenite and arkose, mostly derived from granitic and metamorphic basement rocks typical of the interior of a craton. Primary sedimentary structures include ripples, antidunes, flute and groove casts, cross and parallel lamination, desiccation cracks and soft-sediment deformation structures interpreted as seismites. These findings demonstrate that the sandstones were deposited by supercritical and subcritical flows as well as by unidirectional flows within channels and bars in a river system. Elemental ratios critical of provenance $(\mathrm{La} / \mathrm{Sc}, \mathrm{Th} / \mathrm{Sc}, \mathrm{La} / \mathrm{Cr}, \mathrm{Th} / \mathrm{Cr}$ and $\mathrm{Ba} / \mathrm{Sc})$ are similar to sediments derived from weathering of mostly felsic rocks. Using QmFLt and QtFL ternary diagrams allowed to infer that the sandstones of the Losero Formation were deposited in an active continental margin. Modal analysis of the samples indicates a recycled orogen and dissected arc. Most evidence suggests that the deposit was accumulated in a fluvial environment with conditions ranging from shallow to deep water. Based on these data and field observations, the sandstones from the Losero Formation can be considered as part of the distal facies of the Guanajuato Conglomerate.
\end{abstract}

Keywords: Losero Formation, Guanajuato, Geochemistry, Provenance, Tectonic setting.

\section{Resumen}

Los depósitos de la Formación Losero afloran en el Distrito Minero de Guanajuato, y sobreyacen concordantemente al conglomerado Guanajuato. Los estudios más recientes realizados sobre dicha formación señalan que forma parte de la secuencia volcánica Cenozoica. Sin embargo las evidencias sedimentológicas, petrográficas y geoquímicas sugieren un origen volcánico o sedimentario, el cual no ha sido discutido ampliamente. En este trabajo se presenta un análisis geológico que incluye el levantamiento de ocho columnas estratigráficas con su respectiva toma de muestras, seguido por un análisis petrográfico, geoquímico (ICP-MS), mineralógico mediante Difracción de Rayos-Xy de Microscopio Electrónico de Barrido (SEM). El análisis petrográfico reveló que los depósitos de la Formación Losero están constituidos por litarenitas y arcosas que derivan de un basamento granítico y metamórfico típico de un cratón interior. Las estructuras primarias que presentan son: rizaduras, antidunas, marcas de flutes y grooves, laminación paralela y cruzada, grietas de desecación y estructuras de deformación (sismitas). La presencia de dicha estructuras primarias demuestra que 
dichas areniscas fueron depositadas por flujos supercríticos y sub-críticos así como por flujos unidireccionales dentro de canales y barras de un sistema fluvial. Las razones entre los elementos de procedencia ( $\mathrm{La} / \mathrm{Sc}$, Th/Sc, La/Cr, Th/Cr y Ba/Sc) son similares a las de los sedimentos derivados del intemperismo en su mayoría de rocas félsicas. Mediante los diagramas ternarios QmFLt y QtFL se infirió que las areniscas de la Formación Losero fueron depositadas en un margen continental activo. El análisis modal de las muestras analizadas indican una proveniencia de un orógeno reciclado y un arco disectado. La mayoría de la evidencia sugiere que los depósitos de la Formación Losero se acumularon en un ambiente fluvial con condiciones de flujo somero a profundo. Con base en los resultados obtenidos y las observaciones de campo, las areniscas de la Formación Losero pueden ser consideradas como las facies distales del conglomerado Guanajuato.

Palabras clave: Formación Losero, Guanajuato, Geoquímica, Proveniencia, Ambiente tectónico.

\section{Introduction}

The Losero Formation crops out in the Sierra de Guanajuato (Figure 1), mainly in the Guanajuato Mining District. It is located in the transitional zone between two major volcanic provinces of Mexico: the Paleogene Sierra Madre Occidental (SMO) and the Cenozoic Trans-Mexican Volcanic Belt (TMVB) (Randall et al., 1994). The SMO volcanic sequence consists mainly of silicic ignimbrites and rhyolitic lava domes with ages between the Miocene and Eocene (Nieto-Samaniego et al., 1992; Ferrari et al., 1999). The MVB units are basalts and andesites with middle Miocene to late Pliocene ages and are exposed in the region located immediately southeast of the Guanajuato Mining District (Hasenaka et al., 1994; Valdez-Moreno et al., 1999). The volcanic sequences of the southeastern SMO and the Central TMVB (Gómez-Tuena et al., 2005; Randall et al., 1994) are exposed at the Sierra de Guanajuato. These two sequences overlie Mesozoic metamorphic and sedimentary rocks (Echegoyen-Sánchez et al., 1970; Dávila and Martínez, 1987). The southern Sierra de Guanajuato includes a thick red bed sequence (Guanajuato Conglomerate), rhyolitic tuffs and lava domes (La Bufa and Chichíndaro rhyolite), as well as andesitic volcanoes and lava flows (Cedro Andesite and Calderones). Normal faulting has produced uplifted blocks with N-W, N-S and N-E trends (Cerca-Martínez et al., 2000). The term "Losero Formation" has been previously used in many publications (Orozco, 1921; Guiza, 1949; Schulze, 1953; Edwards, 1955; Echegoyen-Sánchez et al., 1970; Aranda-Gómez et al., 1989; Randall et al., 1994; Aranda-Gómez and Mc Dowell, 1998; Aranda-Gómez et al., 2003); however, no detailed stratigraphic and petrographic descriptions have been available, and its origin has not been sufficiently discussed.

In this work, specific stratigraphic levels of the Losero Formation were studied at eight localities (Calderones, El Faro, Yerbabuena, La Bufa, La Curva, El Socavón, Los Caídos and El Pocito), as shown in Figure 1, in order to determine the origin, paleo-tectonic setting and the depositional environment in which the Losero Formation was accumulated. Geochemistry for major and trace elements, petrography and modal analyses were performed in 46 samples. Furthermore, characteristic sedimentary structures observed in the Losero Formation comprise one of the most invaluable sources of information concerning its depositional environment. Based on these data, the final goal of this work is to establish if the Losero Formation has a purely sedimentary origin (fluvial, lacustrine), volcanic origin (pyroclastic, epiclastic) or mixed origin.

\section{Geological settings}

The Sierra de Guanajuato, located in the Mesa Central province, represents a transition zone between two volcanic provinces of Mexico: the Sierra Madre Occidental (SMO) and the Trans-Mexican Volcanic Belt (Gómez-Tuena et al., 2005; Randall et al., 1994).

The SMO province consists mainly of Oligocene and Miocene silicic ignimbrites and rhyolitic domes (NietoSamaniego et al., 1992; Ferrari et al., 1999). These two sequences rest on metamorphic and sedimentary rocks of Mesozoic age (Echegoyen-Sánchez et al., 1970; Dávila and Martínez, 1987; Martini et al., 2011).

The Sierra de Guanajuato is a NW-SE oriented mountain range with an elevation between 2000 and 2500 m.a.s.1. (Aranda et al., 1989; Cerca-Martínez et al., 2000). This range lies in the central part of the Guerrero Terrane and is constituted by arc sequences, particularly the Late Jurassic early Cretaceous Alisitos-Teloloapan arc (Tardy et al., 1992). The Bajio fault represents an important boundary along the southwesterrn front of the Sierra de Guanajuato and marks the northern limit of the El Bajio depression (Aranda-Gómez et al., 1989; Nieto-Samaniego et al., 1992). The volcanic sequences of the southeastern SMO and the central TMVB are exposed at the Sierra de Guanajuato, represented by silicic ignimbrites, rhyolitic lava domes (Oligocene and Miocene ages) and basalts and andesites of middle Miocene to late Pliocene ages (Aranda- Gómez, et al., 1989; Aguirre-Díaz et al., 1998; Ferrari et al., 1999). Lapierre et al. (1992) and Ortíz-Hernandez et al. (1992) recognized two Mesozoic petrotectonic assemblages in the Sierra de Guanajuato: an intrusive complex and eruptive sequence assemblage and the Guanajuato arc assemblage. The intrusive complex is constituted by gabbro, diorite and tonalite (157 to $120 \mathrm{Ma}$, Lapierre et al., 1992), locally 


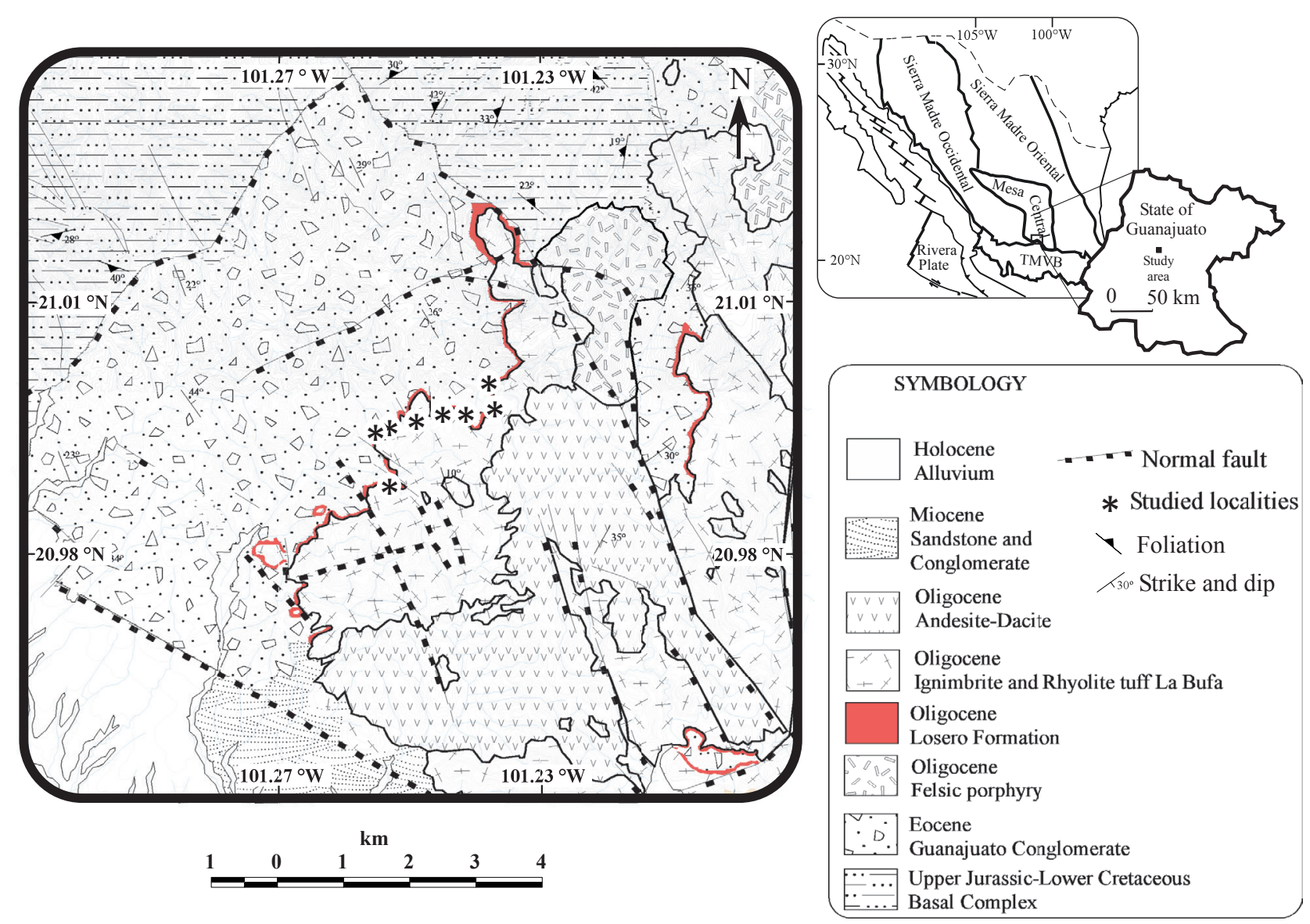

Figure 1. General map of the area of Guanajuato, showing the eight studied locations.

intruded by basaltic and doleritic dikes. The eruptive succession is composed of massive to pillow basalt 108 to $66 \mathrm{Ma}$ in age, (Lapierre et al., 1992) and hyaloclastite interbedded with volcanic breccia, radiolarian chert, arkose, arkosic greywacke and scarce rhyodacitic tuff at the top of the sequence. The Guanajuato arc assemblage has been interpreted by Lapierre et al. (1992) and Tardy et al. (1994) as an intraoceanic arc, built on oceanic crust. Rocks of the arc assemblage overlie in thrust contact of the Arperos Basin assemblage, which consists the Arperos and Esperanza formations (Martini et al., 2011). The Arperos Formation consists of two petrotectonic assemblages: the Arperos and El Paxtle assemblage, (Martini et al., 2011). The Arperos assemblage consists of pillow basalts ( 93 to $85 \mathrm{Ma}$, OrtizHernandez et al., 2003) and hyaloclastite, conformably overlain by volcanic sandstone, shale, radiolarian chert, scarce conglomerate and micritic limestone (OrtizHernandez et al., 2003). On the other hand, the El Paxtle assemblage is constituted by El Paxtle Formation and the Tuna Manza intrusive complex. The Paxtle Formation is composed of pillow basalts and massive basaltic lava flows, hyaloclastite, basaltic tuff, fine grained chert, volcanic sandstones and shale, which are sheared and metamorphosed (Martini et al., 2011). The Esperanza Formation consists of polydeformed metavolcaniclastic rocks and limestone (Echegoyen-Sanchez, 1978). Martini et al. (2011) divided the Esperanza Formation into two units: the Esperanza and Valenciana formations. The Esperanza Formation consist of alternating thin beds of very fine to coarse grained sandstone, thin bedded siltstone, claystone and scarce lensshaped conglomerate strata. The Valenciana Formation consists of finely bedded and laminated micritic limestone and shale. The Esperanza and Valenciana formations are overthrust by the El Paxtle assemblage (Martini et al., 2011). Units characterized by red bed sequences of Cenozoic age (Guanajuato conglomerate and Losero Formation) overlie the Mesozoic assemblage (intrusive complex and eruptive sequence, and Guanajuato arc). Geological evidence suggests that the Cenozoic sequence was contemporaneous with an extensional tectonic setting represented by a synvolcanic conjugated set of normal faults. The Guanajuato conglomerate is considered of Eocene age (FerrusquíaVillafranca, 1987; Aranda-Gómez and McDowell, 1998) with a thickness between 1,500 and 2,000 $\mathrm{m}$ and was divided by Edwards (1955) into two members. The lower member unconformably overlies the Mesozoic assemblage and has a thickness between $900-1,300 \mathrm{~m}$. The base of this member presents conglomerate layers intercalated with 
andesite lava flows. The contact between the lower and upper members is represented by an erosional unconformity of undetermined age (Edwards, 1955). The upper member consists of a matrix supported conglomerate which has a thickness that varies from 170 to $700 \mathrm{~m}$, increasing toward the southeast. The Losero Formation, which overlies the Guanajuato Conglomerate, has been considered as the base of the Oligocene volcanic cover, and has been previously studied by several authors (Orozco, 1921; Guiza, 1949; Schulze, 1953; Edwards, 1955; Echegoyen-Sanchez et al., 1970; Aranda-Gómez et al., 1989; Randall et al., 1994; Aranda-Gómez and Mc Dowell, 1998; Aranda-Gómez et al., 2003, Puy-Alquiza et al., 2013). The origin of the Losero Formation is poorly understood. Orozco (1921) described the Losero Formation as greenish detrital deposits formed by water transporting volcanic tuff, while Guiza (1949) mentioned that this formation is rhyolitic volcanic ash of uniform grain. On the other hand, Schulze (1953) described the Losero Formation as a tuffaceous deposit that resulted from aqueous-igneous flows. Echegoyen-Sánchez et al. (1970) first adopted the name of Losero Formation, following the definitions made by Monroy (1888) and Guiza (1949), who interpreted the deposit as a fine lapilli with a distinctive green color, apparently deposited in water. According to Randall et al. (1994), the Losero Formation is of Oligocene age and could be a surge deposit that preceded the emplacement of Bufa Rhyolite, which is in turn interpreted as a major ignimbrite. Based on this, the most recent interpretation about its origin is that the sequence is essentially made up of subaerial pyroclastic surge layers and tuffs of uncertain eruptive style deposited in (and locally reworked by) shallow water (Aranda-Gómez et al., 2003).

\section{Methods}

Representative samples were collected in eight different localities where the Losero Formation is exposed (in the Guanajuato Mining District), as shown in Figure 1. A detailed description and logging of the rock exposures at the studied locations were made. The first part of the investigation involved field work, sampling and observation and analysis of primary structures. The second part included petrography and major and trace element geochemistry. For the mineralogical study, 46 fresh samples of the Losero Formation were selected as representative for thin-section petrography. Following Ingersoll et al. (1984) pointcounting was employed for quantitative compositional analysis of the different mineral grains. The modal analysis was performed by counting more than 300 points per thin section as done by Gazzi (1966) and Dickinson (1970); rock classification is based on the scheme proposed by Folk (1974). Trace elements composition (Y, Zr, Ti, Nb, Ta, Th, Sc, Hf, Co) was determined using an ICP-MS, and mineralogy by X-ray diffraction and Scanning Electron Microscopy (SEM) at the UNAM laboratories in Juriquilla,
Querétaro.

\section{Results and Discusion}

\subsection{Paleo-environment analysis}

Two stratigraphic members can be clearly distinguished in the Losero Formation (Figure 2). The lower member, about $5 \mathrm{~m}$ thick, is composed mainly of brownish red sandstone and mudstone. Lithofacies are characterized by $\mathrm{Sg}$ (coarse sand with gradation normal), Sh (medium to fine sand with plane-parallel laminae and associated with desiccation cracks), St (medium sand with cross lamination) and Fm (mud, silt with desiccation cracks and cuspate ripple marks; Figure 3). The layering usually consists of beds of coarse to fine sand and mud. Most individual layers extend horizontally for hundreds of meters and a strike of $\mathrm{NW} 83^{\circ} \mathrm{SE}$ with a dip of $35^{\circ} \mathrm{NE}$ can be observed at all locations. This lower member conformably overlies the Guanajuato conglomerate (Figure 3). The upper member, about $25 \mathrm{~m}$ thick, is composed of brownish red and green sandstone and mudstone and is characterized by lithofacies $\mathrm{Sg}$ (coarse sand with normal gradation), Sh (medium to fine sand with plane parallel laminae associated with desiccation cracks), St (medium sand with antidunes and cross laminations), Ss (fine sand with groove casts, flute casts and ripples) and $\mathrm{Sd}$ (soft-sediment deformation structures interpreted as seismites associated with normal faults) (Figure 3 ). The bed strike is $\mathrm{NE} 45^{\circ} \mathrm{SW}$ with a dip of $20^{\circ} \mathrm{SE}$. The main differences between these members observed in the field are the primary sedimentary structures.

\subsubsection{Primary sedimentary structures in the lower member}

The lower member is characterized by the following main primary sedimentary structures (Figure 4): plane parallel laminae, desiccation cracks, ripples and cross bed sets. The plane parallel laminae can be found in medium to fine sand. This primary structure is interpreted as evidence of tractive flow in upper flow regime (Harms, 1979). Some sets of laminae show ondulations and small cusps which indicate products of syn-sedimentary deformation, probably induced by water escaping during deposition. Vertical size grading is commonly observed in the lower part of beds. The mud beds show desiccation cracks of different sizes (1 to $6 \mathrm{~cm}$ ) where the larger cracks truncate the smaller ones. Cuspate ripples are present in the upper portion of some beds and are often associated with desiccation cracks. These ripples present a curve geometry and are discontinuous. They additionally have high amplitude, tuning fork patterns with $10 \mathrm{~cm}$ distance from crest to crest and oriented towards the SE. These ripple types are commonly formed by moderate currents within a lower flow regimen (Harms, 1969). They indicate fluvial environments (channels or channel bars) and are most abundant along the lower reaches of streams where they are associated with parting lineations. They are also 

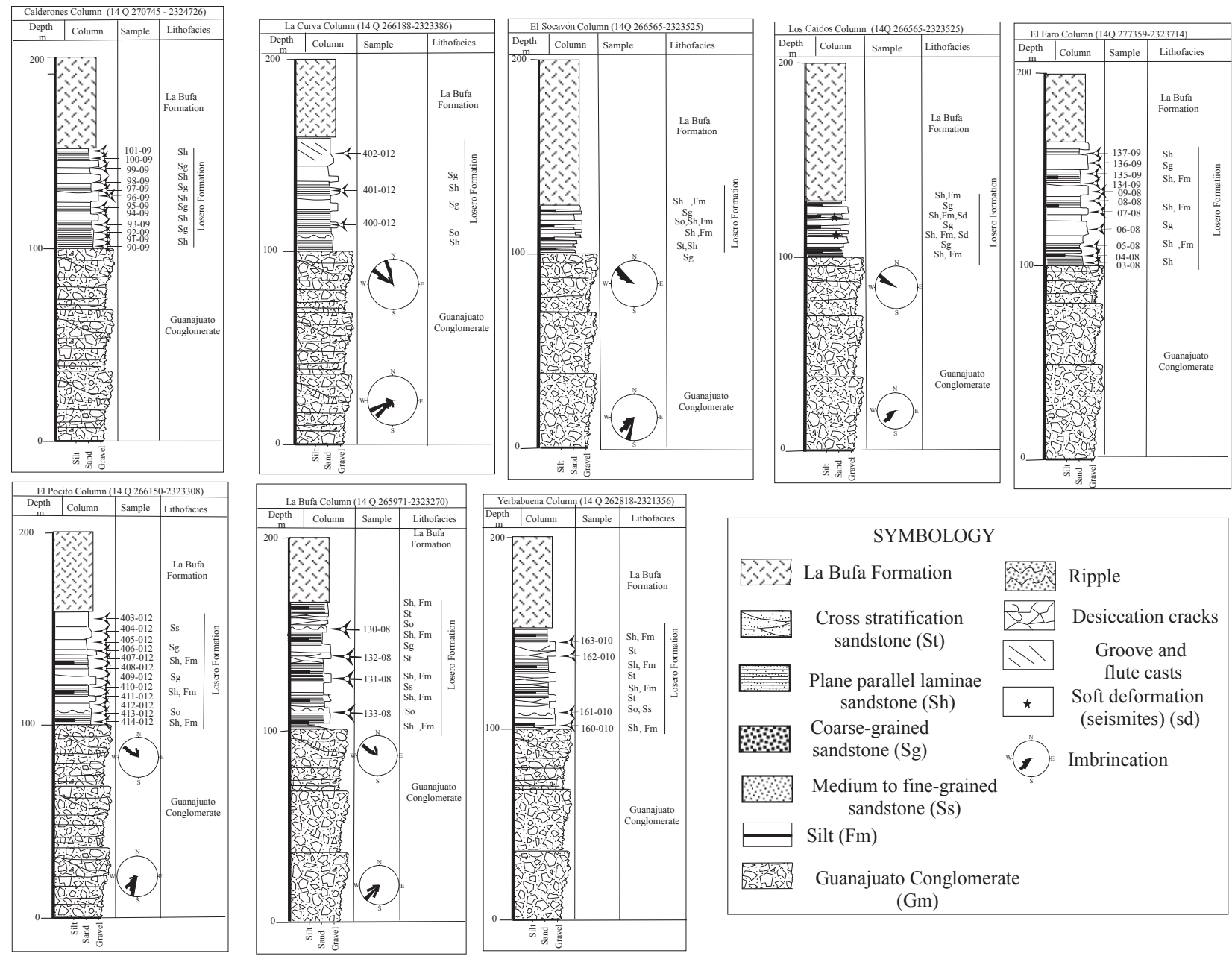

Figure 2. Lithostratigraphic sections of the Losero Formation.

abundant at the distal ends of ephemeral streams (Picard and High, 1973). Another primary structure that can be found in the lower level is the cross bed sets. Most of the sets have a very low angle and seem to be a laterally extensive combination of trough and tabular types. Thickness of individual cross bed sets ranges from 0.5 to $1 \mathrm{~cm}$. The set inclinations vary from 5 to 15 degrees and are oriented invariably towards the SE.

\subsubsection{Primary sedimentary structures in the upper member}

Planar low angle lamination is very common in the upper member (Figure 5) and is present in medium to fine sand. In the upper portion, tectonic features as inclined surfaces and angular contacts can be seen between the beds. Depositional features (lamina set) alternating with erosional features are commonly observed. Both depositional and erosional surfaces are planar and form low angles relative to the horizontal. Thickness of individual laminae sets ranges from 0.5 to $3 \mathrm{~cm}$. The cross-bedded unit contains solitary, isolated trough sets. The set inclinations vary from 5 to 15 degrees and are oriented invariably towards the SE. Thickness of individual cross bed sets range from 0.5 to $1 \mathrm{~cm}$. The trough sets are cut into older, planar laminated sandstone. Planar lamination occupies the lower and middle parts of the bed and long-crested ripples occupy only a few centimeters in the upper part. Some beds lack ripples and display only groove and flute casts. Ripples are asymmetrical, have low amplitude, pointed crests and rounded troughs. They have $1-2 \mathrm{~cm}$ crest distances and their orientation is $65^{\circ} \mathrm{SE}$. The ripples are present above the flutes and groove casts. This is probably due to formation in extremely shallow water, $<2$ m deep, under flow conditions (Tanner, 1967, 1971; Aspler et al., 1994). The depositional couplet of planar lamination capped by oscillation ripples is common in the Losero Formation, which is due to storm events that produced a flow which combined both unidirectional and oscillatory motions. This combined flow resulted in planar laminated sand (Aspler et al., 1994). The antidunes that can be observed are associated with planar laminated sand and they are symmetrical in shape. They show a sinusoidal appearance and their amplitudes reach 1 to $2 \mathrm{~cm}$. These structures are characteristic of supercritical and subcritical flow conditions (Núñez-González and Martín-Vide, 2010). These are also characteristic products under the upper 

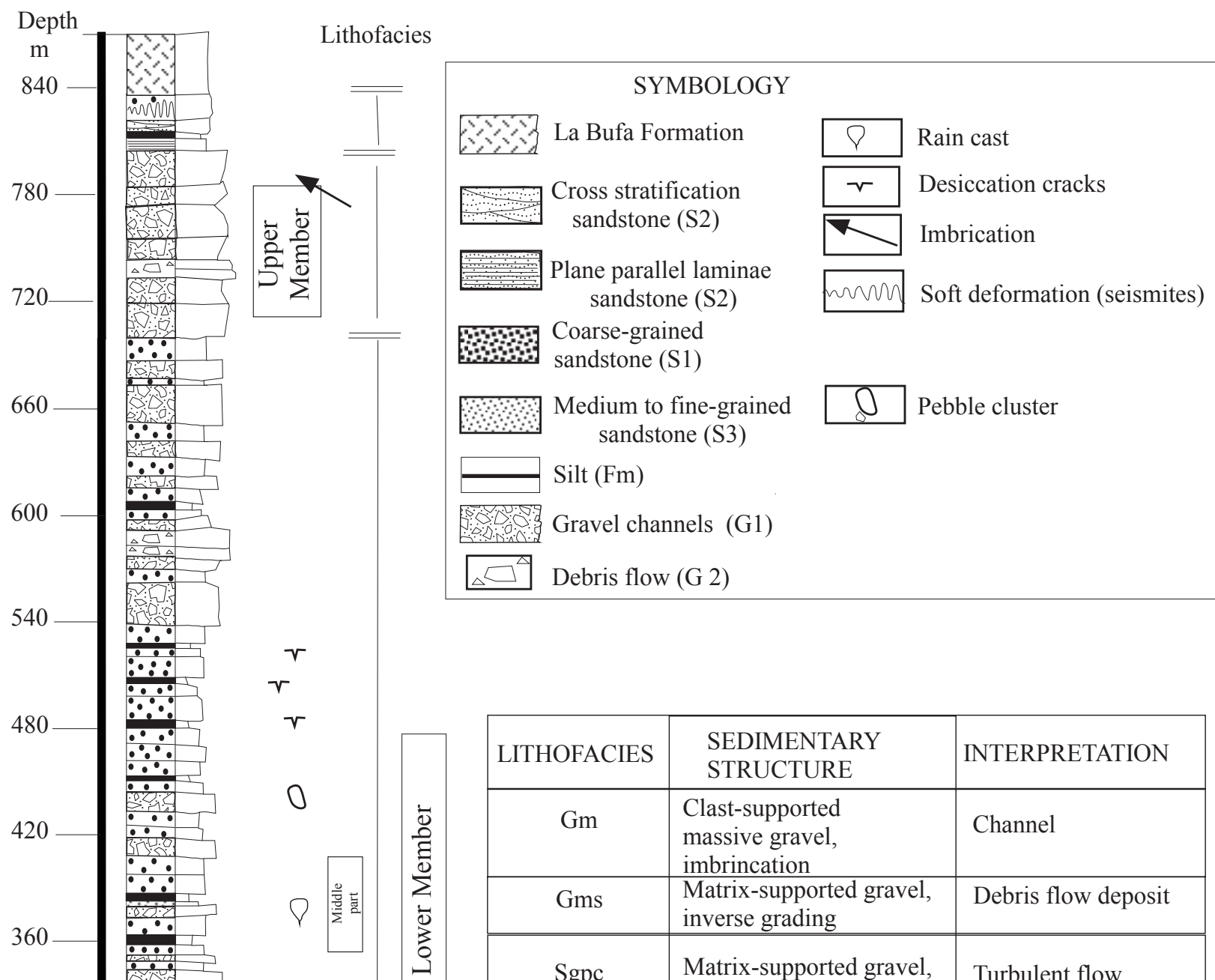

\begin{tabular}{|c|c|c|}
\hline LITHOFACIES & $\begin{array}{l}\text { SEDIMENTARY } \\
\text { STRUCTURE }\end{array}$ & INTERPRETATION \\
\hline $\mathrm{Gm}$ & $\begin{array}{l}\text { Clast-supported } \\
\text { massive gravel, } \\
\text { imbrincation }\end{array}$ & Channel \\
\hline Gms & $\begin{array}{l}\text { Matrix-supported gravel, } \\
\text { inverse grading }\end{array}$ & Debris flow deposit \\
\hline Sgpc & $\begin{array}{l}\text { Matrix-supported gravel, } \\
\text { pebble cluster }\end{array}$ & Turbulent flow \\
\hline $\mathrm{Sg}$ & Sand coarse, massive & Scour fill \\
\hline Sm & $\begin{array}{l}\text { Sand fine to coarse, } \\
\text { massive, inverse grading }\end{array}$ & $\begin{array}{l}\text { Sediment-gravitty } \\
\text { flow deposit }\end{array}$ \\
\hline Ss & $\begin{array}{l}\text { Sand fine to coarse, } \\
\text { shallow scours }\end{array}$ & Scour fill \\
\hline $\mathrm{Sf}$ & Sand fine & Sand bars \\
\hline $\mathrm{Sh}$ & $\begin{array}{l}\text { Sand very fine to coarse, } \\
\text { horizontal lamination }\end{array}$ & Plane-bed flow \\
\hline Fsm & Silt, massive & $\begin{array}{l}\text { Abandoned channel } \\
\text { deposits }\end{array}$ \\
\hline $\mathrm{Fm}$ & $\begin{array}{l}\text { Mud, massive, } \\
\text { desiccation cracks }\end{array}$ & Overbank \\
\hline $\mathrm{Fl}$ & Mud, fine lamination & Overbank \\
\hline
\end{tabular}

Figure 3. Columnar section of the Losero Formation. 

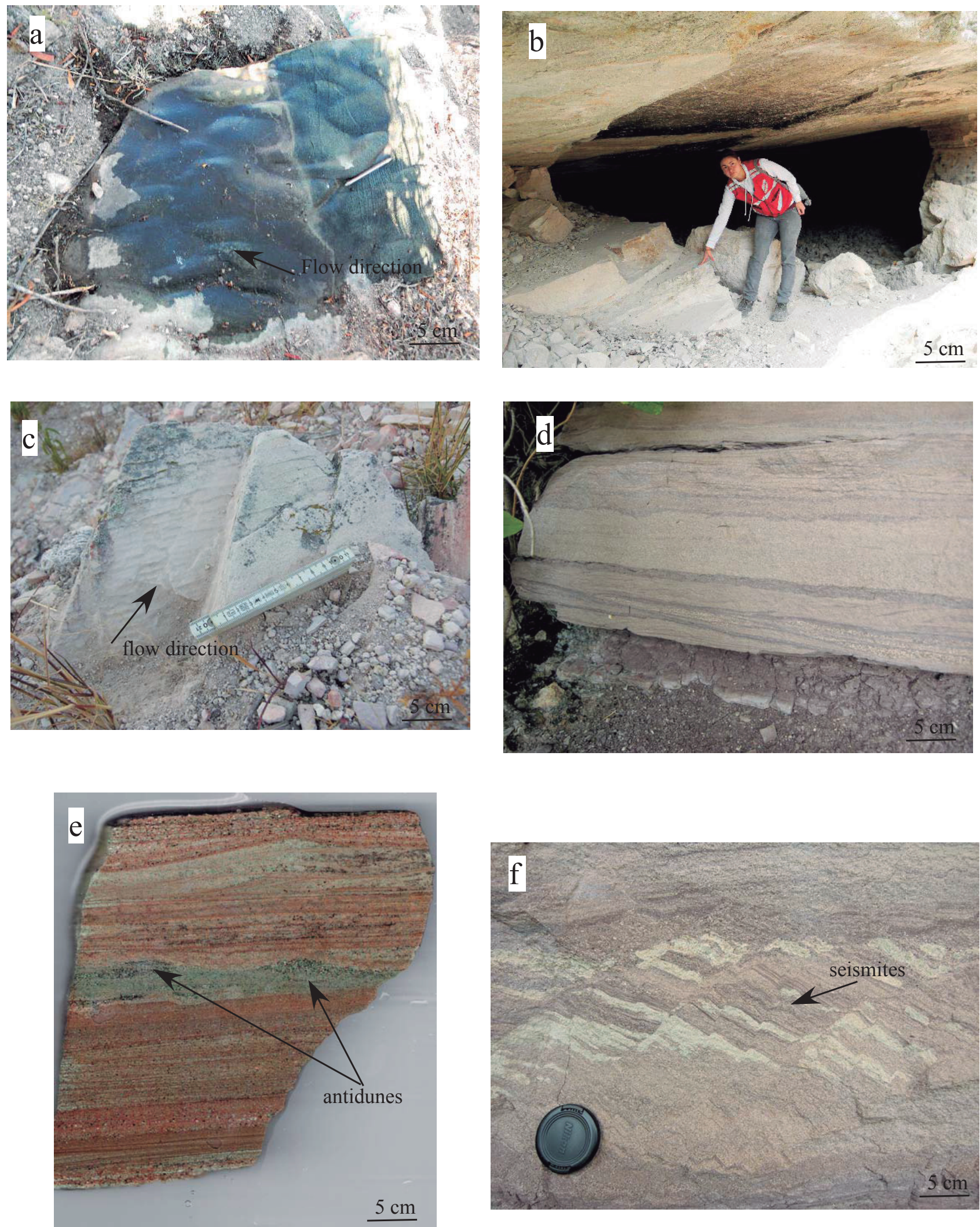

Figure 4. Primary sedimentary structures in the upper member of the Losero Formation: (a) Flute casts; (b) Groove casts; (c) Ripples; (d) Cross bedding; (e) Antidunes; (f) Soft deformation structures (seismites). 

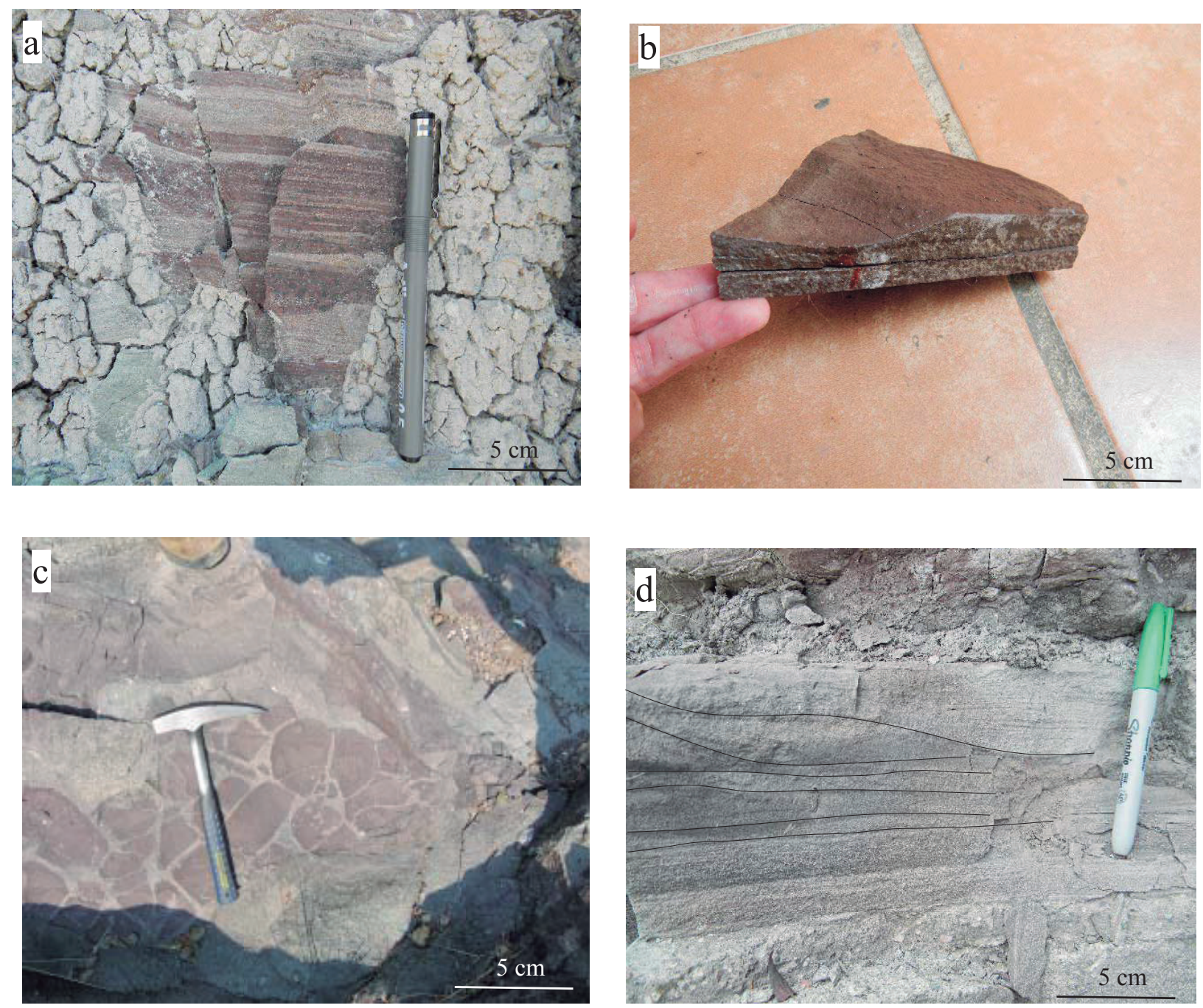

Figure 5. Primary sedimentary structures in the lower member of the Losero Formation: (a) Plane-parallel laminae; (b) Ripples; (c) Desiccation cracks; (d) Cross bedding.

flow regime (Gilbert, 1914). The flutes and groove casts only occupy the bottom part of the bed. Flutes are erosive structures that are produced by movements of a fluid over a cohesive substrate and they are also aligned in rows parallel to the flow. Blunt-nosed cylindrical forms are associated with more pointed and conical forms. They are approximately equal in size and are aligned more or less parallel to each other. The length of the flutes varies from 19 to $22 \mathrm{~cm}$ with an orientation of $35^{\circ} \mathrm{SE}$. The flutes represent sediments that filled depressions on the immediately subjacent bedding plane and they are caused by erosion of freshly deposited mud on an underwater slope (turbidity current) (RicciLucchi, 1995). The groove casts are associated with the flute casts; these are about a millimeter or so in height and 2 to $4 \mathrm{~cm}$ in length and they present an orientation of $45^{\circ}$ towards the SE. They are remarkably straight and some of them are continuously exposed along the exposed bedding plane. This structure is produced by the flow of currents on soft mud (Crowell, 1955; McBride, 1962).
One meter below the Losero-Bufa contact are structures produced by soft-sediment deformation $(\mathrm{Sd})$ which are interpreted as seismites. Some of the sedimentary deformation structures observed in Losero Formation are: asymmetric folds, pseudo-nodules, sand dikes, flame structures, non-sedimentary normal faults and convolute laminae. They are directly related to internal characteristics of sedimentary materials as well as to external factors acting on them. It is important to note that the Losero Formation conformably overlies the Guanajuato Conglomerate, which is observed at the localities of La Bufa, Calderones and Yerbabuena (see Figure 1) where the sand and silt facies of the upper member of the Guanajuato Conglomerate gradually become olive green facies, typical of the Losero Formation.

\subsection{Petrography and modal analysis}

In the Losero Formation, the litharenites are coarse to 
medium grained, whereas arkoses are generally medium to fine grained. Petrographic studies reveal that the framework grains are mainly monocrystalline quartz $(\mathrm{Qm})$, polycrystalline quartz $(\mathrm{Qp})$, feldspars $(\mathrm{F})$, biotite, and rock fragments (L) (Table 1). The most abundant lithic fragments are phyllite, quartzite, andesite and basalt. The matrix is composed of quartz. All the studied samples contain small amounts of potassium feldspar (K). Furthermore, the low potassium values (mean value for $\mathrm{K}_{2} \mathrm{O}=8.18 \mathrm{wt} \%$ ) of the bulk rock analyses of sandstone samples support the petrography results concerning the low K-feldspar content (Table 1). Plagioclase observed in thin sections includes twinned albite and is more abundant than K-feldspar. The $\mathrm{K}$-feldspars are affected by K-feldspathization while albite is partially altered to sericite. Quartz and plagioclase grains are in higher proportions than lithic fragments. Modal analysis from point-counting of the framework grains are presented in Table 1. Monocrystalline quartz $(\mathrm{Qm})$, polycrystalline quartz (Qp), total feldspar (F), and total lithic fragments (Lt) are identified. Petrographic features and composition of the sampled rocks are shown in Figure 6. Sub-angular to subrounded quartz grains are the most common. Sub-angular grains preferentially derived from volcanic and metamorphic rocks (see Figures 6d and 6f). A small quantity of opaque minerals (pyrite, magnetite and hematite) were observed in all samples. Alterations as intermediate argilic, propylitic, sericitic and potassic $\mathrm{K}$-silicate are the most common in all samples. Development of silicate overgrowths with chlorite and calcite replacement of rock fragments and plagioclase becomes more pronounced as burial increases. Using Folk's (1974) classification (QFL ternary plot), results show that the Losero Formation is constituted by lithic-arkoses reflecting their slightly mineralogical immature character (Figure 7A). The geochemical classification diagrams of Pettijohn et al. (1972) considering the boundaries redrawn by Herron (1988) for these sandstones (Figure 7B) show a bimodal distribution with litharenite and arkose clusters. To sum up, the overall petrologic assessment reveals that
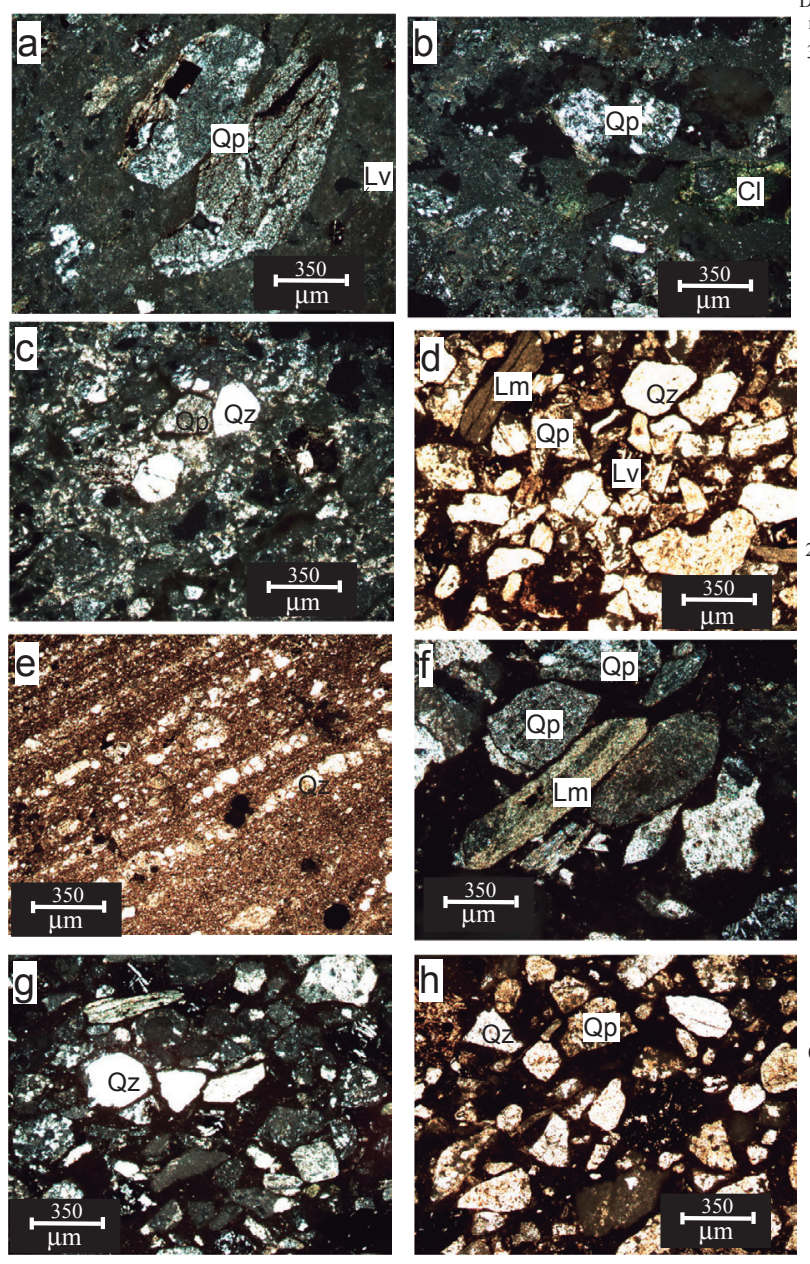

Lithofacies La Bufa Formation

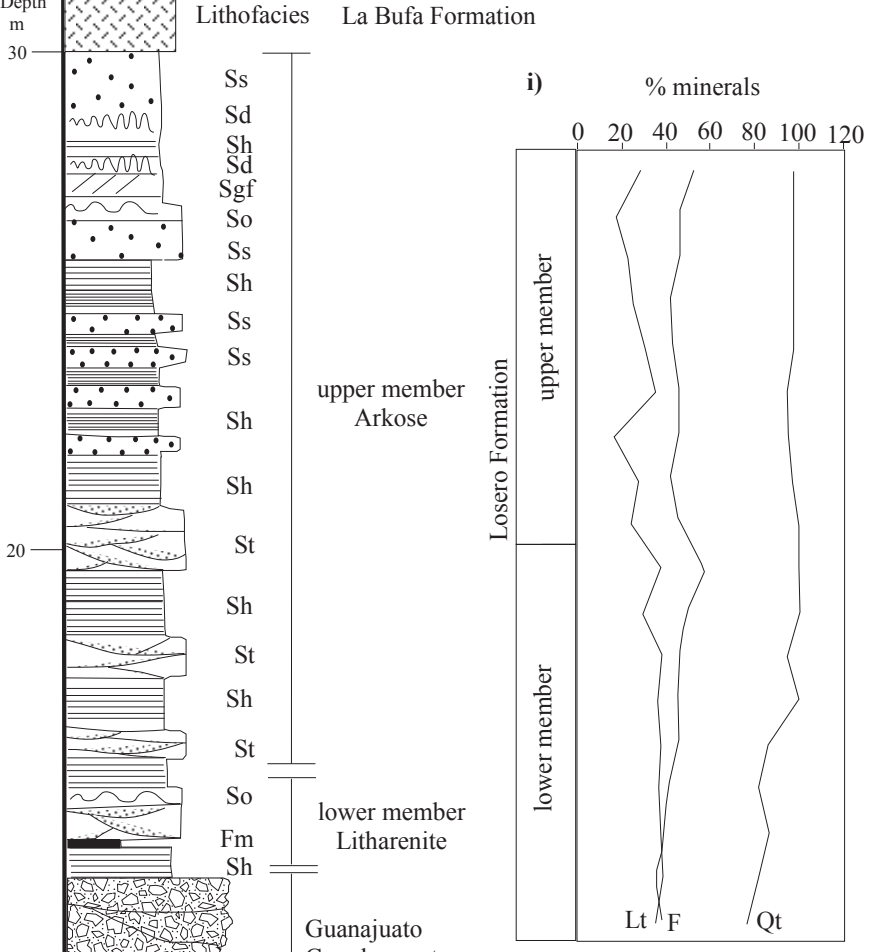

Figure 6. (a,b) Photomicrograph showing quartz grains consisting mainly of polycrystalline quartz grains; (c) Quartz grains consisting mainly of microcrystalline grains; (d) Phyllite and volcanic fragments; (e) Monocrystalline quartz grains and plane parallel laminae; (f) Clast-supported fragments or grains; $(\mathrm{g}, \mathrm{h})$ Monocrystalline and polycrystalline quartz grains, phyllite fragments in silt-clay cement; (i) Petrographic features and composition of the lower and upper member of the Losero Formation. 
(a)

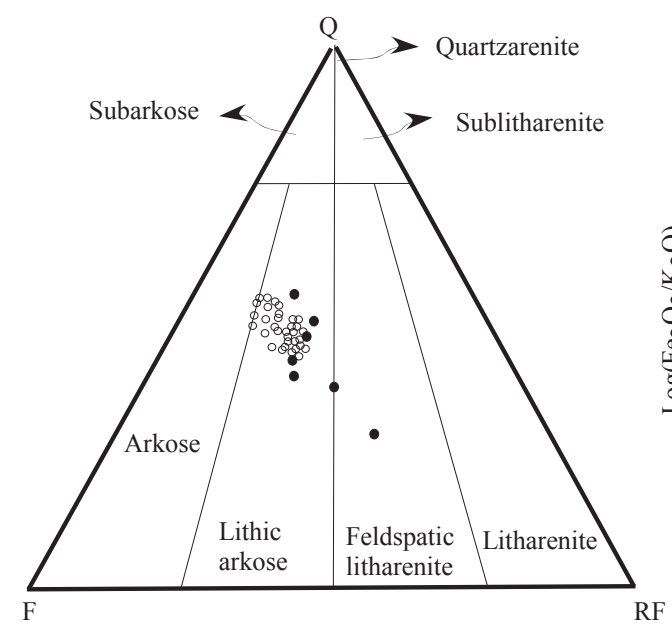

(c) (b)

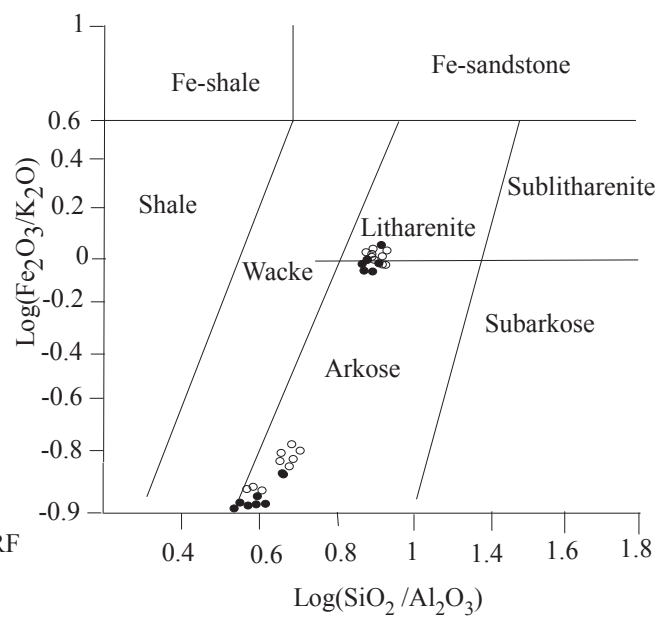

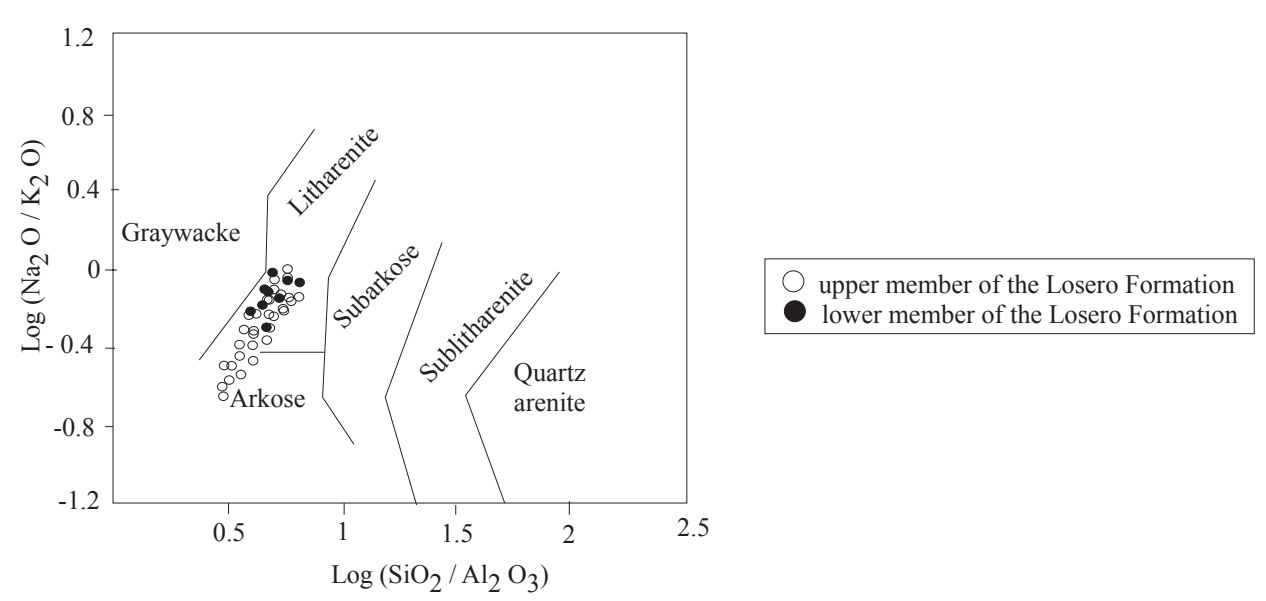

Figure 7. (a) QRF triangular classification plot (Folk, 1974) of sandstone from the Losero Formation; (b) The $\log \left(\mathrm{SiO}_{2} / \mathrm{Al}_{2} \mathrm{O}_{3}\right)$ vs $\mathrm{Log}\left(\mathrm{Fe}_{2} \mathrm{O}_{3} / \mathrm{K}_{2} \mathrm{O}\right)$ diagram of Herron (1988); and (c) Chemical classification of samples of the Losero Formation based on the $\log \left(\mathrm{SiO}_{2} / \mathrm{Al}_{2} \mathrm{O}_{3}\right) \mathrm{vs} \mathrm{Log}\left(\mathrm{Na}_{2} \mathrm{O} / \mathrm{K}_{2} \mathrm{O}\right)$, diagram of Pettijohn et al. (1972).

the observed lithic-arkose can be described as immature sandstone derived from basement uplift, as suggested by the presence of quartz-domination with variable amounts of feldspars and rock fragments, which indicate derivation mainly from acid igneous and metamorphic rocks.

\section{Provenance and tectonic setting}

The use of geochemical composition of sedimentary rocks is a vital tool in understanding the nature of source rocks (Roser and Korsch, 1988; McLennan et al., 1993), as well as the tectonic setting of the depositional basin (Bathia, 1983; Bathia and Crook, 1986; Roser and Korsch,
1986). Provenance analysis is useful in reconstructing the depositional history of sediments or sedimentary rocks. Many attempts have been carried out in order to refine provenance models using framework composition (Dickinson, 1985; Zuffa, 1987), geochemical features (Bathia and Crook, 1986; Roser and Korsch, 1988), and heavy mineral assemblages (Morton, 1985; Chaodong et al., 2005). The major element geochemical parameters proposed by Bhatia (1983), such as $\mathrm{Fe}_{2} \mathrm{O}_{3}+\mathrm{MgO} \%, \mathrm{TiO}_{2} \%,\left(\mathrm{Al}_{2} \mathrm{O} /\right.$ $\left.\mathrm{SiO}_{2}\right),\left(\mathrm{K}_{2} \mathrm{O} / \mathrm{Na}_{2} \mathrm{O}\right)$ and $\left(\mathrm{Al}_{2} \mathrm{O} 3 /\left[\mathrm{CaO}+\mathrm{Na}_{2} \mathrm{O}\right]\right)$ are used to discriminate the plate tectonic setting of sedimentary basins. Roser and Korsch (1986) used the $\mathrm{K}_{2} \mathrm{O} / \mathrm{Na}_{2} \mathrm{O}$ ratio and $\mathrm{SiO}_{2}$ content of published data from an ancient sedimentary suite to define passive margin (PM), active continental 
Table 1. Detrital modes of selected samples of sandstone form the Losero Formation (U, upper member; L lower member). Qm ( monocrystalline quartz); Qp (polycrystalline quartz); Qt (Total quartzs grains [Qm+Qp]); F (Total feldspar grains [P+F]); Lv (volcanic rock fragments); Lm (metasedimentary rock fragments); Lt (Total lithic fragments [Lv+Lm]); Bt (biotite); Ac (Magnetite) (modified after Dickinson, 1985).

\begin{tabular}{|c|c|c|c|c|c|c|c|c|c|c|c|c|c|}
\hline Sample & $Q m$ & $Q p$ & $Q z$ & $F$ & $L v$ & $L s$ & $L m$ & $L t$ & $B t$ & $A c$ & $\begin{array}{l}\text { Cem + } \\
\text { Matrix }\end{array}$ & Total & Alteration \\
\hline $308(\mathrm{U})$ & 62 & 35 & 97 & 52 & 3 & 0 & 25 & 28 & 14 & 0 & 150 & 327 & Intermediate argillic \\
\hline $408(\mathrm{U})$ & 60 & 33 & 93 & 48 & 4 & 0 & 18 & 22 & 3 & 0 & 175 & 338 & Intermediate argillic \\
\hline $508(\mathrm{U})$ & 64 & 34 & 98 & 43 & 6 & 0 & 14 & 20 & 7 & 0 & 155 & 316 & Propylitic \\
\hline $608(U)$ & 62 & 32 & 94 & 42 & 7 & 0 & 12 & 19 & 5 & 0 & 150 & 305 & Potassic, K-silicate \\
\hline $708(\mathrm{U})$ & 64 & 34 & 98 & 43 & 6 & 0 & 14 & 20 & 7 & 0 & 155 & 316 & Potassic, K-silicate \\
\hline 808 (L) & 62 & 38 & 100 & 57 & 23 & 0 & 15 & 38 & 3 & 0 & 95 & 313 & Intermediate argillic \\
\hline $908(U)$ & 62 & 32 & 94 & 42 & 7 & 0 & 12 & 19 & 5 & 0 & 150 & 305 & Intermediate argillic \\
\hline $13008(\mathrm{U})$ & 65 & 32 & 97 & 45 & 6 & 0 & 12 & 18 & 5 & 0 & 150 & 318 & Sericitic, argillic \\
\hline $13108(\mathrm{U})$ & 65 & 32 & 97 & 46 & 8 & 0 & 10 & 18 & 4 & 0 & 165 & 344 & Intermediate argillic \\
\hline $13208(\mathrm{U})$ & 65 & 32 & 97 & 45 & 10 & 0 & 15 & 25 & 5 & 0 & 170 & 355 & Sericitic, argillic \\
\hline $13308(\mathrm{~L})$ & 62 & 38 & 100 & 49 & 25 & 0 & 15 & 30 & 3 & 0 & 95 & 320 & Intermediate argillic \\
\hline 9009 (U) & 67 & 30 & 97 & 45 & 0 & 0 & 22 & 22 & 12 & 12 & 197 & 370 & Potassic, K-silicate \\
\hline 9109 (U) & 65 & 35 & 100 & 43 & 0 & 0 & 25 & 25 & 3 & 10 & 185 & 353 & Potassic, K-silicate \\
\hline 9209 (U) & 62 & 38 & 100 & 46 & 0 & 0 & 27 & 27 & 4 & 12 & 196 & 373 & Intermediate argillic \\
\hline $9309(\mathrm{U})$ & 65 & 30 & 95 & 44 & 0 & 0 & 30 & 30 & 7 & 10 & 187 & 366 & Potassic, K-silicate \\
\hline 9409 (U) & 64 & 30 & 94 & 45 & 0 & 0 & 28 & 28 & 6 & 13 & 196 & 375 & Sericitic, argillic \\
\hline $9509(\mathrm{U})$ & 64 & 34 & 98 & 43 & 0 & 0 & 25 & 25 & 4 & 10 & 198 & 364 & Intermediate argillic \\
\hline $9609(\mathrm{U})$ & 65 & 32 & 97 & 45 & 0 & 0 & 28 & 28 & 6 & 12 & 195 & 371 & Sericitic, argillic \\
\hline $9709(\mathrm{U})$ & 62 & 35 & 97 & 42 & 0 & 0 & 26 & 26 & 7 & 10 & 198 & 363 & Intermediate argillic \\
\hline $9809(\mathrm{U})$ & 65 & 30 & 95 & 45 & 0 & 0 & 28 & 28 & 5 & 11 & 197 & 374 & Intermediate argillic \\
\hline 9909 (U) & 64 & 34 & 98 & 43 & 0 & 0 & 25 & 25 & 4 & 10 & 198 & 364 & Intermediate argillic \\
\hline $10009(\mathrm{U})$ & 62 & 35 & 97 & 42 & 0 & 0 & 26 & 26 & 7 & 10 & 198 & 363 & Potassic, K-silicate \\
\hline $10109(\mathrm{U})$ & 65 & 32 & 97 & 45 & 0 & 0 & 28 & 28 & 6 & 12 & 195 & 371 & Potassic, K-silicate \\
\hline $13409(\mathrm{U})$ & 65 & 35 & 100 & 45 & 10 & 0 & 22 & 32 & 5 & 0 & 210 & 390 & Intermediate argillic \\
\hline 13509 (U) & 64 & 34 & 98 & 43 & 12 & 0 & 19 & 31 & 8 & 0 & 195 & 373 & Intermediate argillic \\
\hline $13609(\mathrm{U})$ & 62 & 37 & 98 & 45 & 10 & 0 & 20 & 30 & 7 & 0 & 210 & 390 & Propylitic \\
\hline $13709(\mathrm{U})$ & 65 & 35 & 100 & 46 & 15 & 0 & 19 & 34 & 5 & 0 & 185 & 371 & Sericitic, argillic \\
\hline $160010(\mathrm{U})$ & 62 & 37 & 99 & 45 & 19 & 0 & 12 & 31 & 3 & 0 & 98 & 301 & Intermediate argillic \\
\hline $161010(\mathrm{U})$ & 65 & 35 & 100 & 45 & 10 & 0 & 14 & 24 & 3 & 0 & 210 & 379 & Potassic, K-silicate \\
\hline $162010(\mathrm{U})$ & 65 & 30 & 95 & 45 & 25 & 0 & 12 & 35 & 3 & 0 & 85 & 300 & Sericitic, argillic \\
\hline $163010(\mathrm{U})$ & 62 & 37 & 99 & 45 & 24 & 0 & 10 & 34 & 3 & 0 & 98 & 301 & Intermediate argillic \\
\hline $400012(\mathrm{U})$ & 65 & 35 & 100 & 45 & 10 & 0 & 14 & 24 & 3 & 0 & 210 & 379 & Intermediate argillic \\
\hline 401012 (U) & 67 & 28 & 95 & 45 & 3 & 0 & 14 & 17 & 17 & 0 & 210 & 378 & Potassic, K-silicate \\
\hline $402012(\mathrm{U})$ & 64 & 34 & 98 & 43 & 12 & 0 & 25 & 37 & 8 & 0 & 195 & 373 & Sericitic, argillic \\
\hline $403012(\mathrm{U})$ & 67 & 28 & 95 & 45 & 3 & 0 & 14 & 17 & 17 & 0 & 210 & 378 & Propylitic \\
\hline 404012 (U) & 64 & 34 & 98 & 43 & 6 & 0 & 17 & 23 & 18 & 0 & 220 & 384 & Potassic, K-silicate \\
\hline 405012 (U) & 72 & 25 & 97 & 38 & 10 & 0 & 14 & 24 & 5 & 0 & 215 & 399 & Intermediate argillic \\
\hline $406012(\mathrm{U})$ & 62 & 35 & 97 & 42 & 12 & 0 & 15 & 27 & 5 & 0 & 225 & 391 & Intermediate argillic \\
\hline 407012 (U) & 65 & 35 & 100 & 45 & 10 & 0 & 14 & 24 & 3 & 0 & 210 & 379 & Sericitic, argillic \\
\hline $408012(\mathrm{~L})$ & 65 & 30 & 95 & 45 & 28 & 0 & 10 & 38 & 3 & 0 & 85 & 300 & Intermediate argillic \\
\hline 409012 (L) & 62 & 37 & 99 & 45 & 25 & 0 & 12 & 37 & 3 & 0 & 98 & 301 & Sericitic, argillic \\
\hline 410012 (L) & 56 & 30 & 86 & 45 & 28 & 0 & 10 & 38 & 0 & 0 & 110 & 308 & Intermediate argillic \\
\hline $411012(\mathrm{~L})$ & 57 & 25 & 82 & 40 & 25 & 0 & 12 & 37 & 0 & 0 & 150 & 327 & Sericitic, argillic \\
\hline 412012 (L) & 59 & 27 & 86 & 39 & 12 & 0 & 26 & 38 & 0 & 0 & 175 & 342 & Intermediate argillic \\
\hline 413012 (L) & 54 & 27 & 81 & 35 & 16 & 0 & 22 & 38 & 9 & 0 & 157 & 314 & Sericitic, argillic \\
\hline 414012 (L) & 52 & 25 & 77 & 36 & 15 & 0 & 20 & 35 & 0 & 0 & 175 & 323 & Intermediate argillic \\
\hline \multicolumn{14}{|c|}{ (46 samples) } \\
\hline Average & 63.1 & 32.6 & 95.76 & 44.1 & 11 & 0 & 22.6 & 33.6 & 5.65 & 28 & 171.43 & & \\
\hline Standard Deviation & 3.44 & 3.54 & 5.2 & 3.51 & 11.3 & 0 & 7.14 & 15.6 & 4.16 & 4.91 & 40.93 & & \\
\hline Min & 52 & 25 & 77 & 35 & 0 & 0 & 10 & 17 & 0 & 0 & 85 & & \\
\hline Max & 72 & 38 & 100 & 57 & 35 & 0 & 38 & 72 & 18 & 13 & 225 & & \\
\hline
\end{tabular}


margin (ACM) and oceanic island arc (ARC) settings. McLennan et al. (1993), as well as Taylor and McLennan (1985), have noted that concentrations of major trace and rare earth elements (REE) of sediments are well suited to constrain provenance and source rock composition due to the fact that the REE content is transferred with minimal fractionation from the source material into the sediments. Consequently, elemental ratios such as $\mathrm{La} / \mathrm{Sc}, \mathrm{La} / \mathrm{Co}, \mathrm{Th} /$
Sc and $\mathrm{Zr} / \mathrm{Cr}$, as well as $\mathrm{La}, \mathrm{Th}$, and $\mathrm{Zr}$ content (Ronov et al., 1974; Wronkiewicz and Condie, 1987, 1990), have proved to be good discriminators between mafic and felsic source rocks. Based on this, the $\mathrm{Th} / \mathrm{Sc}$ ratios range from 0.86 to 1.02 for the lower member, and 0.90 to 2.07 for the upper member (Table 2). La/Th ratios range from 1.85 to 2.13 for the lower member, and 1.65 to 3.14 for the upper member (see Table 2). These data suggest a mixed source

Table 2. Ratios of Th/Sc, $\mathrm{La} / \mathrm{Th}, \mathrm{Zr} / \mathrm{Sc}, \mathrm{Th} / \mathrm{Cr}, \mathrm{Cr} / \mathrm{V}, \mathrm{La} / \mathrm{Co}, \mathrm{La} / \mathrm{Th}, \mathrm{La} / \mathrm{Cr}, \mathrm{Zr} / \mathrm{Cr}, \mathrm{Th} / \mathrm{Co}, \mathrm{Cr} / \mathrm{Th}$ and $\mathrm{Y} / \mathrm{Ni}$ for the lower member (L) and upper member (U), Inductively Coupled Plasma Mass Spectrometry (ICP-MS).

\begin{tabular}{|c|c|c|c|c|c|c|c|c|c|c|c|c|c|}
\hline Sample & $\mathbf{T h} / \mathbf{S c}$ & $\mathrm{Zr} / \mathrm{Sc}$ & $\mathrm{La} / \mathrm{Sc}$ & $\mathbf{T h} / \mathbf{C r}$ & $\mathrm{Cr} / \mathrm{V}$ & $\mathrm{La} / \mathrm{Co}$ & $\mathbf{B a} / \mathbf{S c}$ & $\mathbf{L a} / \mathbf{T h}$ & $\mathrm{La} / \mathrm{Cr}$ & $\mathrm{Zr} / \mathrm{Cr}$ & Th/Co & $\mathrm{Cr} / \mathrm{Th}$ & $\mathbf{Y} / \mathbf{N i}$ \\
\hline $308(U)$ & 1.04 & 7.92 & 1.72 & 0.34 & 0.48 & 3.57 & 114.48 & 1.65 & 0.56 & 2.75 & 2.16 & 2.93 & 1.64 \\
\hline $408(U)$ & 1.3 & 11.86 & 2.79 & 0.27 & 0.67 & 3.31 & 142.33 & 2.14 & 0.57 & 2.43 & 1.55 & 3.75 & 1.76 \\
\hline $508(\mathrm{U})$ & 1.4 & 11.42 & 2.51 & 0.65 & 0.53 & 4 & 114.19 & 1.8 & 1.16 & 4.52 & 2.22 & 1.55 & 4.42 \\
\hline $608(U)$ & 1.88 & 11.42 & 3.64 & 1.11 & 0.53 & 8 & 146.97 & 1.94 & 2.14 & 7.68 & 4.13 & 0.9 & 7.6 \\
\hline $708(\mathrm{U})$ & 1.43 & 11.42 & 3.12 & 1.03 & 0.53 & 7.08 & 105.24 & 2.18 & 2.26 & 6.69 & 3.24 & 0.97 & 8.6 \\
\hline $808(\mathrm{~L})$ & 1.02 & 8.06 & 2.05 & 0.35 & 0.36 & 3 & 86.21 & 2.01 & 0.71 & 2.79 & 1.49 & 2.84 & 3.12 \\
\hline $908(\mathrm{U})$ & 0.9 & 7.92 & 1.88 & 0.27 & 0.48 & 2.43 & 96.25 & 2.09 & 0.56 & 2.25 & 1.16 & 3.72 & 2.27 \\
\hline 13008(U) & 1.3 & 11.86 & 2.79 & 0.27 & 0.67 & 3.33 & 142.33 & 2.14 & 0.57 & 2.43 & 1.56 & 3.75 & 1.77 \\
\hline 13108(U) & 1.04 & 7.92 & 1.72 & 0.34 & 0.48 & 3.33 & 114.48 & 1.65 & 0.56 & 2.75 & 2.02 & 2.93 & 1.57 \\
\hline $13208(U)$ & 1.3 & 11.86 & 2.79 & 0.27 & 0.67 & 3 & 142.33 & 2.14 & 0.57 & 2.43 & 1.4 & 3.75 & 1.78 \\
\hline $13308(\mathrm{~L})$ & 1 & 8.06 & 2.07 & 0.48 & 0.36 & 3 & 85.17 & 2.07 & 1 & 3.83 & 1.45 & 2.07 & 3.09 \\
\hline 9009(U) & 1.43 & 11.42 & 3.12 & 1.03 & 0.53 & 6.89 & 105.24 & 2.18 & 2.26 & 6.69 & 3.16 & 0.97 & 8.63 \\
\hline 9109(U) & 1.88 & 11.42 & 3.64 & 1.11 & 0.53 & 8 & 146.97 & 1.94 & 2.14 & 7.68 & 4.13 & 0.9 & 7.6 \\
\hline 9209(U) & 1.04 & 7.92 & 1.72 & 0.34 & 0.48 & 3.33 & 114.48 & 1.65 & 0.56 & 2.75 & 2.02 & 2.93 & 1.57 \\
\hline 9309(U) & 1.43 & 11.42 & 3.12 & 1.03 & 0.53 & 6.89 & 105.24 & 2.18 & 2.26 & 6.69 & 3.16 & 0.97 & 9.2 \\
\hline 9409(U) & 1.3 & 11.86 & 2.79 & 0.27 & 0.67 & 3 & 142.33 & 2.14 & 0.57 & 2.43 & 1.4 & 3.75 & 1.78 \\
\hline 9509(U) & 0.9 & 7.92 & 1.88 & 0.27 & 0.48 & 3 & 96.25 & 2.09 & 0.56 & 2.25 & 1.43 & 3.72 & 2.27 \\
\hline 9609(U) & 1.3 & 11.86 & 2.79 & 0.27 & 0.67 & 3.08 & 142.33 & 2.14 & 0.57 & 2.43 & 1.44 & 3.75 & 1.8 \\
\hline 9709(U) & 1 & 7.92 & 1.67 & 0.33 & 0.48 & 3.45 & 110.67 & 1.67 & 0.56 & 2.72 & 2.07 & 3 & 1.59 \\
\hline 9809(U) & 1.54 & 11.42 & 3.73 & 0.79 & 0.53 & 6.57 & 125.95 & 2.42 & 1.92 & 5.24 & 2.71 & 1.26 & 2.99 \\
\hline 9909(U) & 0.86 & 7.92 & 1.8 & 0.27 & 0.48 & 3 & 92.4 & 2.09 & 0.56 & 2.25 & 1.43 & 3.72 & 2.27 \\
\hline 10009(U) & 1.88 & 11.42 & 3.64 & 1.03 & 0.53 & 7.5 & 146.97 & 1.94 & 2 & 7.17 & 3.88 & 0.97 & 7.04 \\
\hline 10109(U) & 2.07 & 11.42 & 4 & 1.03 & 0.53 & 8 & 162 & 1.94 & 2 & 8.17 & 4.13 & 0.97 & 8 \\
\hline $13409(\mathrm{U})$ & 1.01 & 7.92 & 1.67 & 0.34 & 0.48 & 3.57 & 110.67 & 1.65 & 0.56 & 2.39 & 2.16 & 2.98 & 1.64 \\
\hline 13509(U) & 1.43 & 11.42 & 3.5 & 0.81 & 0.53 & 6.67 & 116.5 & 2.46 & 2 & 5.43 & 2.71 & 1.23 & 2.94 \\
\hline $13609(\mathrm{U})$ & 1.41 & 11.42 & 2.56 & 0.65 & 0.53 & 4.07 & 114.19 & 1.82 & 1.18 & 4.52 & 2.24 & 1.53 & 4.34 \\
\hline 13709(U) & 1.3 & 11.86 & 2.79 & 0.27 & 0.67 & 3.31 & 142.33 & 2.14 & 0.57 & 2.43 & 1.55 & 3.75 & 1.8 \\
\hline $160010(\mathrm{U})$ & 0.88 & 7.92 & 1.8 & 0.28 & 0.48 & 3.33 & 92.4 & 2.05 & 0.56 & 2.25 & 1.63 & 3.64 & 2.3 \\
\hline $161010(\mathrm{U})$ & 1.88 & 11.42 & 3.64 & 1.03 & 0.53 & 7.5 & 146.97 & 1.94 & 2 & 7.17 & 3.88 & 0.97 & 7.04 \\
\hline $162010(\mathrm{U})$ & 1.3 & 11.86 & 2.79 & 0.27 & 0.67 & 3 & 142.33 & 2.14 & 0.57 & 2.43 & 1.4 & 3.75 & 1.96 \\
\hline $163010(\mathrm{U})$ & 1.04 & 7.92 & 1.72 & 0.34 & 0.48 & 3.45 & 114.48 & 1.65 & 0.56 & 2.75 & 2.09 & 2.93 & 1.62 \\
\hline 400012(U) & 1.62 & 11.42 & 3.73 & 0.83 & 0.53 & 6.57 & 125.95 & 2.3 & 1.92 & 5.24 & 2.86 & 1.2 & 3.56 \\
\hline 401012(U) & 1.43 & 11.42 & 3.12 & 1.03 & 0.53 & 6.55 & 105.24 & 2.18 & 2.26 & 6.69 & 3 & 0.97 & 9.2 \\
\hline 402012(U) & 1.91 & 11.42 & 3.14 & 1.29 & 0.53 & 6.76 & 137.16 & 1.65 & 2.13 & 7.59 & 4.11 & 0.77 & 5.85 \\
\hline 403012(U) & 1.4 & 11.42 & 2.86 & 0.67 & 0.53 & 6.47 & 114.19 & 2.05 & 1.37 & 4.67 & 4.16 & 1.5 & 6.88 \\
\hline 404012(U) & 2 & 11.42 & 4 & 1 & 0.53 & 4.29 & 161.67 & 2 & 2 & 7.17 & 2.14 & 1 & 3.52 \\
\hline 405012(U) & 1.24 & 7.92 & 1.8 & 0.41 & 0.48 & 5.29 & 92.4 & 1.45 & 0.6 & 2.4 & 3.65 & 2.42 & 6.54 \\
\hline 406012(U) & 1.1 & 11.42 & 3.45 & 0.63 & 0.53 & 4.93 & 116.5 & 3.14 & 1.97 & 5.71 & 1.57 & 1.59 & 2.7 \\
\hline 407012(U) & 1.4 & 11.86 & 2.79 & 0.29 & 0.67 & 3.24 & 142.33 & 2 & 0.57 & 1.81 & 1.62 & 3.5 & 1.79 \\
\hline 408012(L) & 1.03 & 8.06 & 2.08 & 0.47 & 0.36 & 3.01 & 87.54 & 2.02 & 0.96 & 3.61 & 1.49 & 2.11 & 3.03 \\
\hline 409012(L) & 1 & 8.06 & 2.13 & 0.46 & 0.36 & 3.09 & 85.17 & 2.13 & 0.98 & 4.26 & 1.45 & 2.17 & 3.09 \\
\hline 410012(L) & 1 & 8.06 & 2 & 0.5 & 0.36 & 2.8 & 81.43 & 2 & 1 & 3.31 & 1.4 & 2 & 3 \\
\hline 411012(L) & 1 & 8.06 & 2 & 0.46 & 0.36 & 3.08 & 82.5 & 2 & 0.92 & 4.15 & 1.54 & 2.17 & 3.19 \\
\hline 412012(L) & 0.86 & 8.06 & 2 & 0.37 & 0.36 & 2.5 & 87.54 & 2.32 & 0.87 & 3.07 & 1.08 & 2.68 & 2.53 \\
\hline 413012(L) & 1.12 & 8.06 & 2.07 & 0.46 & 0.36 & 2.86 & 85.17 & 1.85 & 0.86 & 3.36 & 1.55 & 2.15 & 3.16 \\
\hline 414012(L) & 1 & 8.06 & 2 & 0.54 & 0.36 & 2.59 & 81.43 & 2 & 1.08 & 4.15 & 1.3 & 1.86 & 2.78 \\
\hline
\end{tabular}


of sediments. Floyd and Leveridge (1987) stated that the elemental ratio of $\mathrm{La} / \mathrm{Th}$ plotted versus the concentration of hafnium (Hf) demonstrates the degree of recycling in sandstones and it also provides information about the provenance. In this study, $\mathrm{La} / \mathrm{Sc}, \mathrm{Th} / \mathrm{Sc}, \mathrm{La} / \mathrm{Co}$, and $\mathrm{Th} / \mathrm{Co}$ values of the sandstones of the Losero Formation are more similar to values of those sediments derived from felsic rocks than those for mafic rocks (Table 3 ). The $\mathrm{La} / \mathrm{Th}$ versus Hf plot for the sandstone of the Losero Formation shows intense recycling and sedimentary source (Figure 8). In a La-Th-Sc diagram (Figure 8), used to discriminate felsic and basic provenance, the sediment data fell in a specific region that indicates a predominantly felsic source, but does not exclude an intermediate source or possible mixing between felsic and basic source rock. The maximum Ba and
Table 3. Range of elemental ratios from sandstones from the Losero Formation compared to elemental ratios in sediments derived from felsic rocks, mafic rocks, and in the upper Continental Crust. ${ }^{1}$ Cullers (2000); Cullers and Podkovyrov (2000); Cullers et al. (1988). ${ }^{2}$ McLennan (2001); Taylor and McLennan (1985).

\begin{tabular}{ccccc}
\hline $\begin{array}{c}\text { Elemental } \\
\text { ratio }\end{array}$ & $\begin{array}{c}\text { Upper } \\
\text { Continental } \\
\text { Crust }^{2}\end{array}$ & $\begin{array}{c}\text { Range of } \\
\text { sediment } \\
\text { from mafic } \\
\text { sources }^{1}\end{array}$ & $\begin{array}{c}\text { Range of } \\
\text { sediment } \\
\text { from felsic } \\
\text { sources }\end{array}$ & $\begin{array}{c}\text { Range of } \\
\text { sandstones } \\
\text { from } \\
\text { Losero } \\
\text { Formation }\end{array}$ \\
\hline $\mathrm{La} / \mathrm{Sc}$ & 2.21 & $0.43-0.86$ & $2.50-16.3$ & $1.67-3.64$ \\
$\mathrm{Th} / \mathrm{Sc}$ & 0.79 & $0.05-0.22$ & $0.84-20.5$ & $0.86-2.07$ \\
$\mathrm{La} / \mathrm{Co}$ & 1.76 & $0.14-0.38$ & $1.80-13.8$ & $2.43-8.0$ \\
$\mathrm{Th} / \mathrm{Co}$ & 0.63 & $0.04-1.40$ & $0.67-19.4$ & $1.16-4.16$ \\
$\mathrm{Cr} / \mathrm{Th}$ & 7.76 & $25-500$ & $4.00-15.0$ & $0.77-3.75$ \\
\hline
\end{tabular}

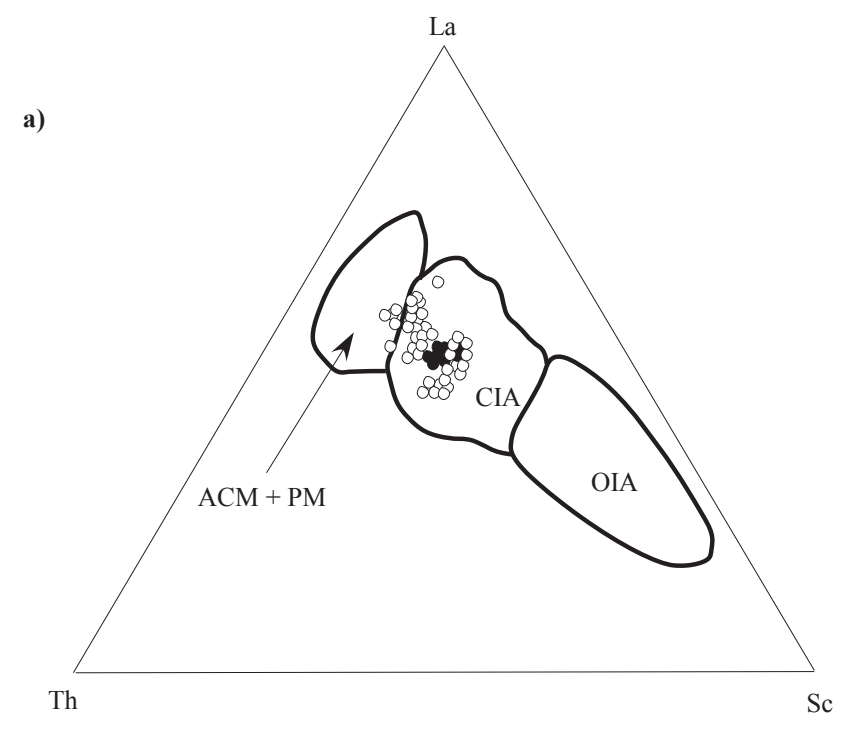

b)

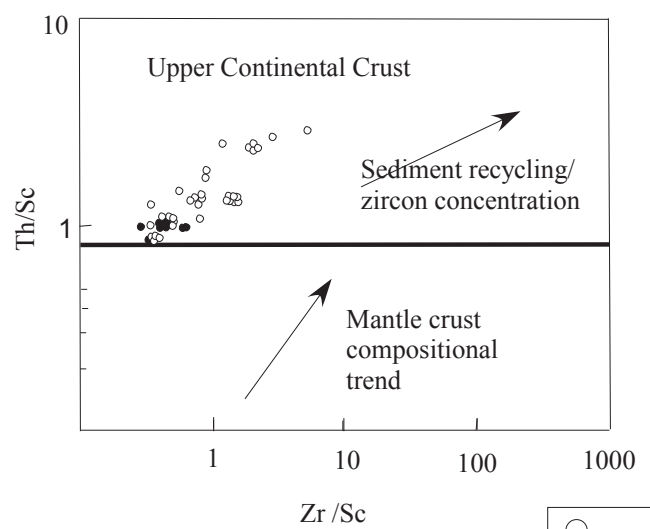

c)

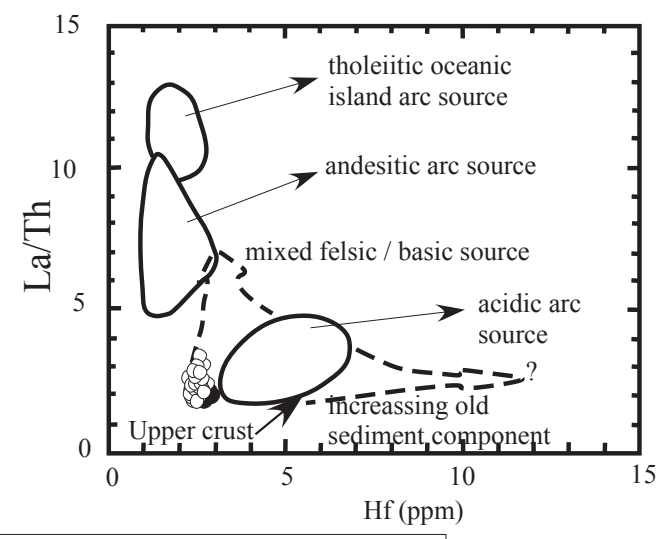

upper member of the Losero Formation lower member of the Losero Formation

Figure 8. (a) Plot La-Th-Sc of sandstone from the Losero Formation (after Bathia and Crook, 1986); (b) Plot of Th/Sc versus $\mathrm{Zr} / \mathrm{Sc}$ of sandstone from the Losero Formation (modified after McLennan et al. 1993); (c) Source rock Hf-La/Th, discrimination diagram for the discussion of the clastic sediments and their compositions (Floyd and Leveridge, 1987) for sandstone from the Losero Formation. 
Sr concentrations in sandstones of the Losero Formation 611 ppm and 186 ppm, respectively (Table 4). The high Ba and $\mathrm{Sr}$ contents could suggest a stream sediment environment (Keshav et al., 2011).

Particularly, this high Ba enrichment can be attributed to feldspar weathering in silicate rocks. High levels of $\mathrm{Sr}$ are commonly found in acidic rocks, such as granite (Keshav et al., 2011). The sandstones have low $\mathrm{Sc}, \mathrm{Fe}, \mathrm{Cr}$ and $\mathrm{Co}$ contents and high concentrations of the REE, Th, and Hf, and high $\mathrm{La} / \mathrm{Sc}, \mathrm{Th} / \mathrm{Sc}, \mathrm{La} / \mathrm{Cr}, \mathrm{Th} / \mathrm{Cr}$ and $\mathrm{Ba} / \mathrm{Sc}$ ratios (Figure 9), indicating that they were derived mainly from felsic rocks (Cullers et al., 1987, 1988). The studied rocks are rich in $\mathrm{Rb}(88 \mathrm{ppm}$ and $190 \mathrm{ppm})$ when compared to the average North America Shale Composite (NASC). The $\mathrm{Cr} / \mathrm{V}$ values vary between 0.36 and 0.67 and $\mathrm{Y} / \mathrm{Ni}$ values range between 1.64 and 9.2 (Table 2). In order to use major elements for provenance interpretations, the discriminant functions of Roser and Korsch (1988) were considered using $\mathrm{Al}_{2} \mathrm{O}_{3}, \mathrm{TiO}_{2}, \mathrm{SiO}_{2}, \mathrm{Na}_{2} \mathrm{O}$, and $\mathrm{K}_{2} \mathrm{O}$ contents as variables. In Figure 10, the majority of the samples from the Losero Formation plot in the felsic igneous provenance field. This is equivalent to an active continental margin tectonic setting (Bhatia, 1983), (Figure 10). In the QtFL and QmFLt ternary diagrams of Dickinson et al. (1983), the point counting data plot in the recycled orogen and dissected arc (Figure 11).

\section{Conclusions}

Based on a comprehensive study in studied rocks of the Losero Formation (petrography, geochemistry, modal analyses and ternary diagrams), this succession is interpreted as being formed by arkoses and litharenites. The following evidence that supports this interpretation is:

Table 4. Whole rock trace element composition of sandstones from the Losero Formation. Elemental concentrations are in parts per million. U (upper member), L(lower member), Inductively Coupled Plasma Mass Spectrometry (ICP-MS).

\begin{tabular}{|c|c|c|c|c|c|c|c|c|c|c|c|c|c|c|c|c|c|c|c|c|c|c|c|}
\hline Sample & Sc & $\mathbf{T i}$ & $\mathbf{V}$ & $\mathrm{Cr}$ & $\mathbf{G a}$ & $\mathbf{R b}$ & $\mathrm{Sr}$ & $\mathbf{Y}$ & $\mathbf{Z r}$ & $\mathbf{N b}$ & Cs & $\mathbf{B a}$ & $\mathbf{L a}$ & $\mathrm{Ce}$ & Nd & Sm & Eu & $\mathbf{T b}$ & Gd & Ta & $\mathbf{P b}$ & Th & $\mathbf{U}$ \\
\hline $308 \mathrm{U}$ & 5.3 & 0.1 & 35 & 17 & 13 & 150 & 97 & 13 & 42 & 6.4 & 10 & 563 & 9 & 20 & 8 & 2 & 0.3 & 0.3 & 1.9 & 0.9 & 17 & 5 & 2.8 \\
\hline $408 \mathrm{U}$ & 4.3 & 0.1 & 31 & 21 & 17 & 129 & 137 & 19 & 51 & 8.1 & 16 & 611 & 12 & 24 & 12 & 3 & 0.4 & 0.5 & 3 & 1.1 & 49 & 6 & 3.6 \\
\hline $508 \mathrm{U}$ & 3.5 & 0.1 & 12 & 6.4 & 15 & 111 & 185 & 20 & 40 & 8 & 12 & 475 & 13 & 27 & 12 & 3 & 0.3 & 0.5 & 3 & 1.2 & 18 & 6 & 3.5 \\
\hline $608 \mathrm{U}$ & 3.5 & 0.1 & 12 & 6.4 & 15 & 111 & 185 & 20 & 40 & 8 & 12 & 475 & 13 & 27 & 12 & 3 & 0.3 & 0.5 & 3 & 1.2 & 18 & 6 & 3.5 \\
\hline $708 \mathrm{U}$ & 3.5 & 0.1 & 12 & 6.4 & 15 & 111 & 185 & 20 & 40 & 8 & 12 & 475 & 13 & 27 & 12 & 3 & 0.3 & 0.5 & 3 & 1.2 & 18 & 6 & 3.5 \\
\hline $808 \mathrm{~L}$ & 6.2 & 0.2 & 36 & 13 & 16 & 134 & 186 & 23 & 50 & 8 & 16 & 531 & 13 & 28 & 13 & 3 & 0.5 & 0.6 & 3 & 1.2 & 18 & 6 & 3 \\
\hline $908 \mathrm{U}$ & 5.3 & 0.1 & 35 & 17 & 13 & 150 & 97 & 13 & 42 & 6.4 & 10 & 563 & 9 & 20 & 8 & 2 & 0.3 & 0.3 & 1.9 & 0.9 & 17 & 5 & 2.8 \\
\hline $13008 \mathrm{U}$ & 4.3 & 0.1 & 31 & 21 & 17 & 129 & 137 & 19 & 51 & 8.1 & 16 & 611 & 12 & 24 & 12 & 3 & 0.4 & 0.5 & 3 & 1.1 & 49 & 6 & 3.6 \\
\hline $13108 \mathrm{U}$ & 5.3 & 0.1 & 35 & 17 & 13 & 150 & 97 & 13 & 42 & 6.4 & 10 & 563 & 9 & 20 & 8 & 2 & 0.3 & 0.3 & 1.9 & 0.9 & 17 & 5 & 2.8 \\
\hline $13208 \mathrm{U}$ & 4.3 & 0.1 & 31 & 21 & 17 & 129 & 137 & 19 & 51 & 8.1 & 16 & 611 & 12 & 24 & 12 & 3 & 0.4 & 0.5 & 3 & 1.1 & 49 & 6 & 3.6 \\
\hline $13308 \mathrm{~L}$ & 6.2 & 0.2 & 36 & 13 & 16 & 134 & 186 & 23 & 50 & 8 & 16 & 531 & 13 & 28 & 13 & 3 & 0.5 & 0.6 & 3 & 1.2 & 18 & 6 & 3 \\
\hline $9009 \mathrm{U}$ & 3.5 & 0.1 & 12 & 6.4 & 15 & 111 & 185 & 20 & 40 & 8 & 12 & 475 & 13 & 27 & 12 & 3 & 0.3 & 0.5 & 3 & 1.2 & 18 & 6 & 3.5 \\
\hline $9109 \mathrm{U}$ & 3.5 & 0.1 & 12 & 6.4 & 15 & 111 & 185 & 20 & 40 & 8 & 12 & 475 & 13 & 27 & 12 & 3 & 0.3 & 0.5 & 3 & 1.2 & 18 & 6 & 3.5 \\
\hline $9209 \mathrm{U}$ & 5.3 & 0.1 & 35 & 17 & 13 & 150 & 97 & 13 & 42 & 6.4 & 10 & 563 & 9 & 20 & 8 & 2 & 0.3 & 0.3 & 1.9 & 0.9 & 17 & 5 & 2.8 \\
\hline $9309 \mathrm{U}$ & 3.5 & 0.1 & 12 & 6.4 & 15 & 111 & 185 & 20 & 40 & 8 & 12 & 475 & 13 & 27 & 12 & 3 & 0.3 & 0.5 & 3 & 1.2 & 18 & 6 & 3.5 \\
\hline $9409 \mathrm{U}$ & 4.3 & 0.1 & 31 & 21 & 17 & 129 & 137 & 19 & 51 & 8.1 & 16 & 611 & 12 & 24 & 12 & 3 & 0.4 & 0.5 & 3 & 1.1 & 49 & 6 & 3.6 \\
\hline $9509 \mathrm{U}$ & 5.3 & 0.1 & 35 & 17 & 13 & 150 & 97 & 13 & 42 & 6.4 & 10 & 563 & 9 & 20 & 8 & 2 & 0.3 & 0.3 & 1.9 & 0.9 & 17 & 5 & 2.8 \\
\hline $9609 \mathrm{U}$ & 4.3 & 0.1 & 31 & 21 & 17 & 129 & 137 & 19 & 51 & 8.1 & 16 & 611 & 12 & 24 & 12 & 3 & 0.4 & 0.5 & 3 & 1.1 & 49 & 6 & 3.6 \\
\hline $9709 \mathrm{U}$ & 5.3 & 0.1 & 35 & 17 & 13 & 150 & 97 & 13 & 42 & 6.4 & 10 & 563 & 9 & 20 & 8 & 2 & 0.3 & 0.3 & 1.9 & 0.9 & 17 & 5 & 2.8 \\
\hline $9809 \mathrm{U}$ & 3.5 & 0.1 & 12 & 6.4 & 15 & 111 & 185 & 20 & 40 & 8 & 12 & 475 & 13 & 27 & 12 & 3 & 0.3 & 0.5 & 3 & 1.2 & 18 & 6 & 3.5 \\
\hline $9909 \mathrm{U}$ & 5.3 & 0.1 & 35 & 17 & 13 & 150 & 97 & 13 & 42 & 6.4 & 10 & 563 & 9 & 20 & 8 & 2 & 0.3 & 0.3 & 1.9 & 0.9 & 17 & 5 & 2.8 \\
\hline $10009 \mathrm{U}$ & 3.5 & 0.1 & 12 & 6.4 & 15 & 111 & 185 & 20 & 40 & 8 & 12 & 475 & 13 & 27 & 12 & 3 & 0.3 & 0.5 & 3 & 1.2 & 18 & 6 & 3.5 \\
\hline $10109 \mathrm{U}$ & 3.5 & 0.1 & 12 & 6.4 & 15 & 111 & 185 & 20 & 40 & 8 & 12 & 475 & 13 & 27 & 12 & 3 & 0.3 & 0.5 & 3 & 1.2 & 18 & 6 & 3.5 \\
\hline $13409 \mathrm{U}$ & 5.3 & 0.1 & 35 & 17 & 13 & 150 & 97 & 13 & 42 & 6.4 & 10 & 563 & 9 & 20 & 8 & 2 & 0.3 & 0.3 & 1.9 & 0.9 & 17 & 5 & 2.8 \\
\hline $13509 \mathrm{U}$ & 3.5 & 0.1 & 12 & 6.4 & 15 & 111 & 185 & 20 & 40 & 8 & 12 & 475 & 13 & 27 & 12 & 3 & 0.3 & 0.5 & 3 & 1.2 & 18 & 6 & 3.5 \\
\hline $13609 \mathrm{U}$ & 3.5 & 0.1 & 12 & 6.4 & 15 & 111 & 185 & 20 & 40 & 8 & 12 & 475 & 13 & 27 & 12 & 3 & 0.3 & 0.5 & 3 & 1.2 & 18 & 6 & 3.5 \\
\hline $13709 \mathrm{U}$ & 4.3 & 0.1 & 31 & 21 & 17 & 129 & 137 & 19 & 51 & 8.1 & 16 & 611 & 12 & 24 & 12 & 3 & 0.4 & 0.5 & 3 & 1.1 & 49 & 6 & 3.6 \\
\hline $160010 \mathrm{U}$ & 5.3 & 0.1 & 35 & 17 & 13 & 150 & 97 & 13 & 42 & 6.4 & 10 & 563 & 9 & 20 & 8 & 2 & 0.3 & 0.3 & 1.9 & 0.9 & 17 & 5 & 2.8 \\
\hline $161010 \mathrm{U}$ & 3.5 & 0.1 & 12 & 6.4 & 15 & 111 & 185 & 20 & 40 & 8 & 12 & 475 & 13 & 27 & 12 & 3 & 0.3 & 0.5 & 3 & 1.2 & 18 & 6 & 3.5 \\
\hline $162010 \mathrm{U}$ & 4.3 & 0.1 & 31 & 21 & 17 & 129 & 137 & 19 & 51 & 8.1 & 16 & 611 & 12 & 24 & 12 & 3 & 0.4 & 0.5 & 3 & 1.1 & 49 & 6 & 3.6 \\
\hline $163010 \mathrm{U}$ & 5.3 & 0.1 & 35 & 17 & 13 & 150 & 97 & 13 & 42 & 6.4 & 10 & 563 & 9 & 20 & 8 & 2 & 0.3 & 0.3 & 1.9 & 0.9 & 17 & 5 & 2.8 \\
\hline $400012 \mathrm{U}$ & 3.5 & 0.1 & 12 & 6.4 & 15 & 111 & 185 & 20 & 40 & 8 & 12 & 475 & 13 & 27 & 12 & 3 & 0.3 & 0.5 & 3 & 1.2 & 18 & 6 & 3.5 \\
\hline $401012 \mathrm{U}$ & 3.5 & 0.1 & 12 & 6.4 & 15 & 111 & 185 & 20 & 40 & 8 & 12 & 475 & 13 & 27 & 12 & 3 & 0.3 & 0.5 & 3 & 1.2 & 18 & 6 & 3.5 \\
\hline $402012 \mathrm{U}$ & 3.5 & 0.1 & 12 & 6.4 & 15 & 111 & 185 & 20 & 40 & 8 & 12 & 475 & 13 & 27 & 12 & 3 & 0.3 & 0.5 & 3 & 1.2 & 18 & 6 & 3.5 \\
\hline $403012 \mathrm{U}$ & 3.5 & 0.1 & 12 & 6.4 & 15 & 111 & 185 & 20 & 40 & 8 & 12 & 475 & 13 & 27 & 12 & 3 & 0.3 & 0.5 & 3 & 1.2 & 18 & 6 & 3.5 \\
\hline $404012 \mathrm{U}$ & 3.5 & 0.1 & 12 & 6.4 & 15 & 111 & 185 & 20 & 40 & 8 & 12 & 475 & 13 & 27 & 12 & 3 & 0.3 & 0.5 & 3 & 1.2 & 18 & 6 & 3.5 \\
\hline $405012 \mathrm{U}$ & 5.3 & 0.1 & 35 & 17 & 13 & 150 & 97 & 13 & 42 & 6.4 & 10 & 563 & 9 & 20 & 8 & 2 & 0.3 & 0.3 & 1.9 & 0.9 & 17 & 5 & 2.8 \\
\hline $406012 \mathrm{U}$ & 3.5 & 0.1 & 12 & 6.4 & 15 & 111 & 185 & 20 & 40 & 8 & 12 & 475 & 13 & 27 & 12 & 3 & 0.3 & 0.5 & 3 & 1.2 & 18 & 6 & 3.5 \\
\hline $407012 \mathrm{U}$ & 4.3 & 0.1 & 31 & 21 & 17 & 129 & 137 & 19 & 51 & 8.1 & 16 & 611 & 12 & 24 & 12 & 3 & 0.4 & 0.5 & 3 & 1.1 & 49 & 6 & 3.6 \\
\hline $408012 \mathrm{~L}$ & 6.2 & 0.2 & 36 & 13 & 16 & 134 & 186 & 23 & 50 & 8 & 16 & 531 & 13 & 28 & 13 & 3 & 0.5 & 0.6 & 3 & 1.2 & 18 & 6 & 3 \\
\hline $409012 \mathrm{~L}$ & 6.2 & 0.2 & 36 & 13 & 16 & 134 & 186 & 23 & 50 & 8 & 16 & 531 & 13 & 28 & 13 & 3 & 0.5 & 0.6 & 3 & 1.2 & 18 & 6 & 3 \\
\hline $410012 \mathrm{~L}$ & 6.2 & 0.2 & 36 & 13 & 16 & 134 & 186 & 23 & 50 & 8 & 16 & 531 & 13 & 28 & 13 & 3 & 0.5 & 0.6 & 3 & 1.2 & 18 & 6 & 3 \\
\hline $411012 \mathrm{~L}$ & 6.2 & 0.2 & 36 & 13 & 16 & 134 & 186 & 23 & 50 & 8 & 16 & 531 & 13 & 28 & 13 & 3 & 0.5 & 0.6 & 3 & 1.2 & 18 & 6 & 3 \\
\hline $412012 \mathrm{~L}$ & 6.2 & 0.2 & 36 & 13 & 16 & 134 & 186 & 23 & 50 & 8 & 16 & 531 & 13 & 28 & 13 & 3 & 0.5 & 0.6 & 3 & 1.2 & 18 & 6 & 3 \\
\hline $413012 \mathrm{~L}$ & 6.2 & 0.2 & 36 & 13 & 16 & 134 & 186 & 23 & 50 & 8 & 16 & 531 & 13 & 28 & 13 & 3 & 0.5 & 0.6 & 3 & 1.2 & 18 & 6 & 3 \\
\hline $414012 \mathrm{~L}$ & 6.2 & 0.2 & 36 & 13 & 16 & 134 & 186 & 23 & 50 & 8 & 16 & 531 & 13 & 28 & 13 & 3 & 0.5 & 0.6 & 3 & 1.2 & 18 & 6 & 3 \\
\hline
\end{tabular}


- The primary structures observed in the Losero Formation are ripples, antidunes, flute and groove casts, cross and parallel lamination, and desiccation cracks.

- The primary structures show that the sedimentation occurred in fluvial, shallow and deep water flow environments.

- The syn-sedimentary features and the presence of seismites highlight the strong influence of tectonic activity during the Eocene in the Losero Formation with earthquakes of moderate magnitude which were capable of liquefying the sediment.

- Paleocurrent data (flute and groove casts) indicate that sediment in the Losero Formation was derived from a northwest source area.

- Trace element concentrations in the rocks of the Losero indicate deposition in an active continental setting that received detritus from the source areas.

- The high Ba and Sr concentrations (611 ppm and 186 $\mathrm{ppm}$, respectively) reinforce the interpretation of a a)
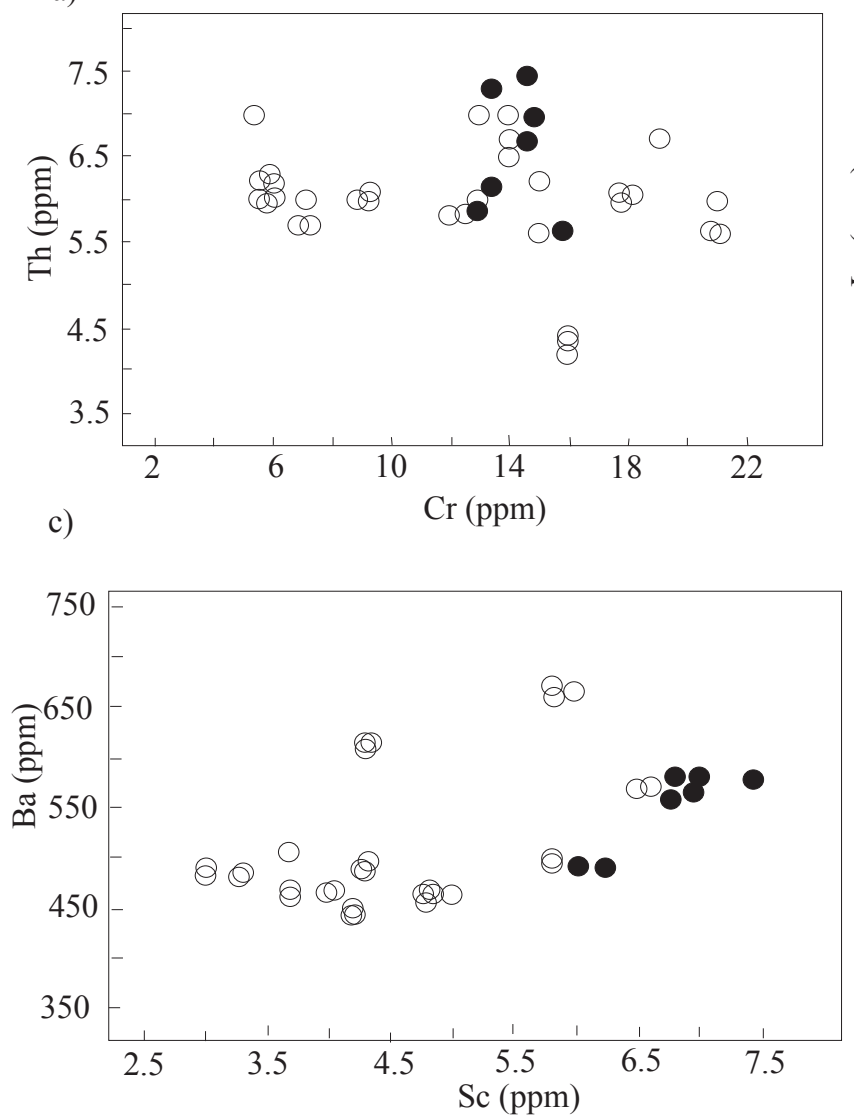

e)

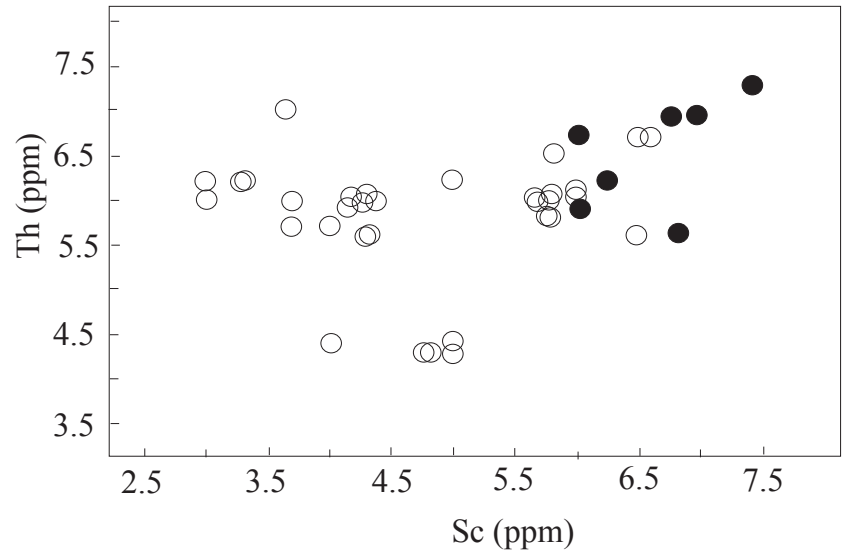

b)

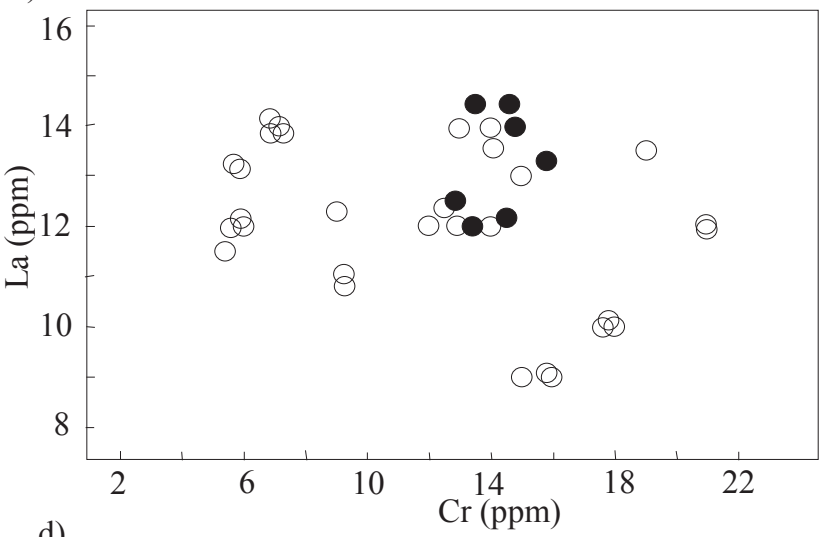

d)

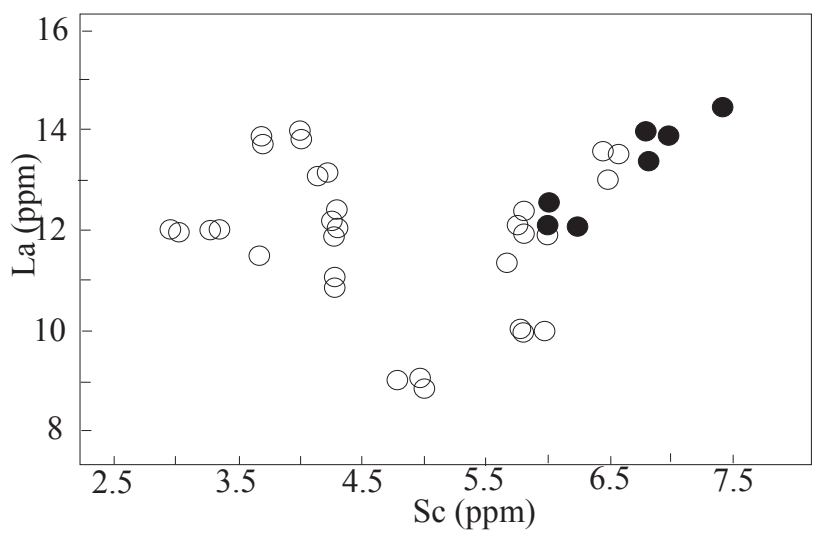

Figure 9. Plots of (a) Th vs Cr; (b) La vs Cr; (c) Ba vs Sc; (d) La vs Sc; (e) Th vs Sc. 
a)

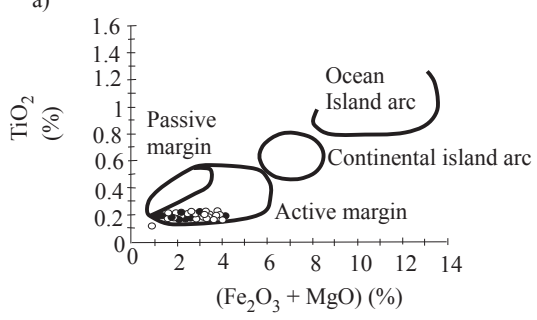

b)

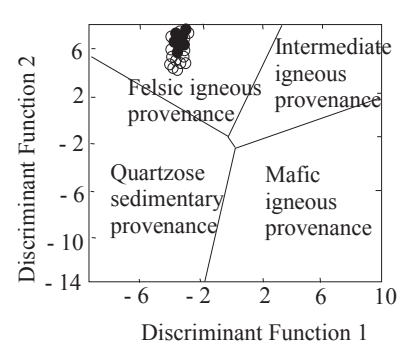

upper member of the Losero Formation

lower member of the Losero Formation

Figure 10. Discrimination diagrams for sandstone from the Losero Formation. (a) Bivariate plot of $\mathrm{TiO}_{2} v s\left(\mathrm{Fe}_{2} \mathrm{O}_{3}+\mathrm{MgO}\right)$ (after Bathia, 1983); (b) Discriminant function diagram for the provenance signatures (after Roser and Korsch, 1988). sedimentary origin in detriment of a volcanic origin.

- The $\mathrm{Th} / \mathrm{Sr}$ ratios range from 0.86 to 2.07 and La/ Th from 1.65 to 3.14 , suggesting a mixed source of sediment.

- The low contents of $\mathrm{Sc}, \mathrm{Fe}, \mathrm{Cr}$ and $\mathrm{Co}$, and high, La/ $\mathrm{Sc}, \mathrm{Th} / \mathrm{Sc}, \mathrm{La} / \mathrm{Cr}, \mathrm{Th} / \mathrm{Cr}$ and $\mathrm{Ba} / \mathrm{Sc}$ ratios and $\mathrm{Th}$ and $\mathrm{Hf}$ concentrations indicate that they were derived mainly from felsic rocks.

- The QtFLt and QmFLt ternary plots indicate a recycled orogen and dissected arc. The recycled orogen source derived from Mesozoic rocks of the Sierra de Guanajuato. This composition shows that the core of the Sierra de Guanajuato was exposed during the early Cenozoic.

- Based on all the described evidences, it is proposed that the Losero Formation sandstones represent the distal facies of the Guanajuato conglomerate.

\section{Acknowledgements}

This research was conducted with the financial support of DINPO-University of Guanajuato, Project 000044/09.

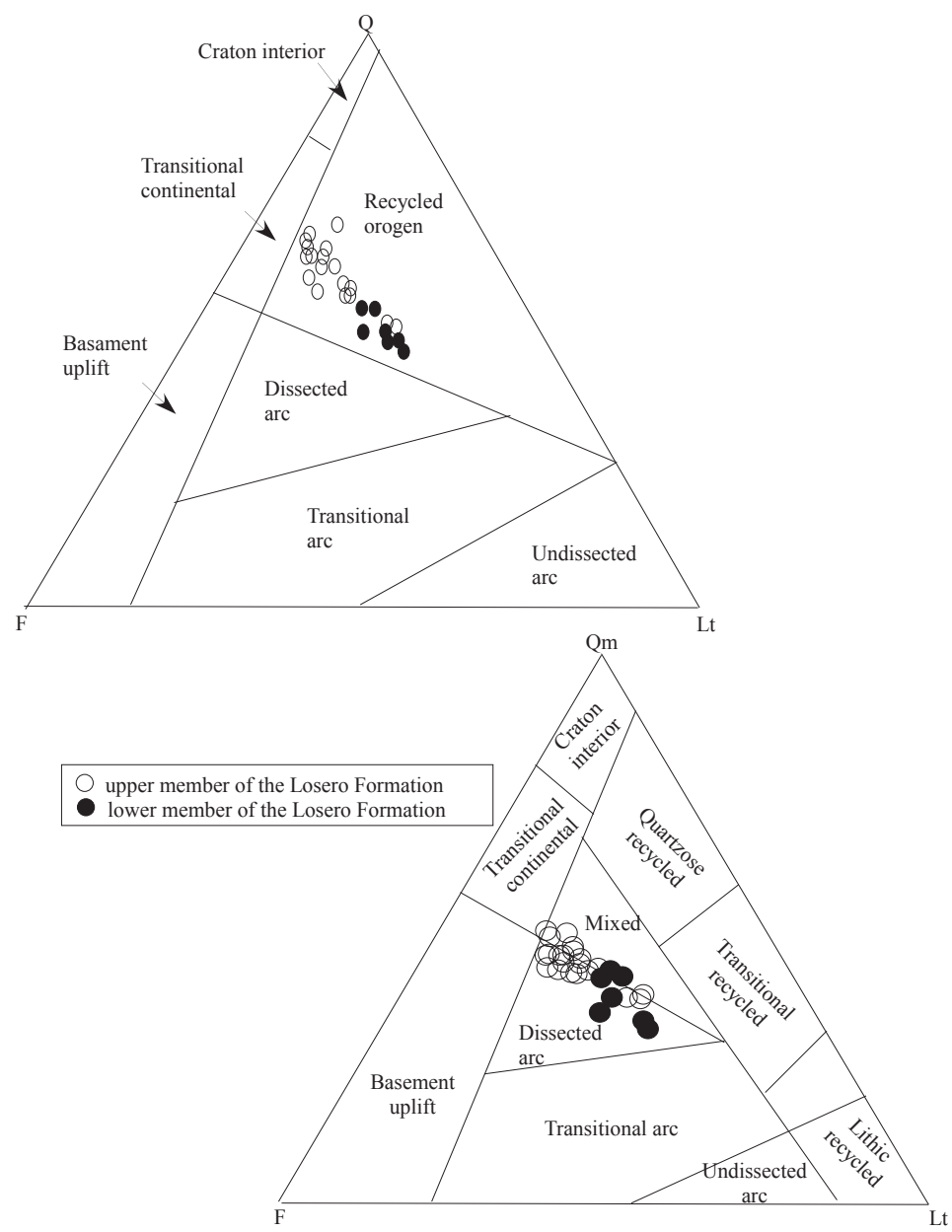

Figure 11. QFLt and QmFLt ternary diagrams for sandstone of the Losero Formation based on Dickinson et al. (1983). 


\section{References}

Aguirre-Díaz, G.J., Ferrari, L., Nelson, S.A., Carrasco-Núñez, G., LópezMartínez, M., Urrutia-Fucugauchi, J., 1998, Un nuevo proyecto multidisciplinario: Unión Geofísica Mexicana, GEOS, 18, 131-138.

Aranda-Gómez, J.J., Mc Dowell, F.W., 1998, Paleogene extension in the southern basin and range province of México: Syndepositional tilting of Eocene red beds and Oligocene volcanic rocks in the Guanajuato mining district: International Geology Review, 40, 116-134.

Aranda-Gómez, J.G., Aranda-Gómez, J.M., Nieto-Samaniego, A.F., 1989, Consideraciones acerca de la evolución tectónica durante El Cenozoico de La Sierra de Guanajuato y la parte meridional de la Mesa Central: Revista Instituto Geología, Universidad Nacional Autónoma de México, 2, 33-46.

Aranda-Gómez, J.J., Godchaux, M.M., Aguirre-Díaz, G.J., Bonnichsen, B., Martínez-Reyes, J., 2003, Three superimposed volcanic arcs in the southern Cordillera from the Early Cretaceous to the Miocene, Guanajuato, Mexico, Guidebook for field trips of the 99th Annual Meeting of the Cordilleran section of the geological Society of America, Puerto Vallarta, Mexico, April 5-8: Universidad Nacional Autónoma de México, Instituto de Geología, Publicación especial 1, Field trip 6, 123-168.

Aspler, L.B., Chiarenzelli, J.R., Ozarko, D.L., Powis, K.B., 1994, Geology of Archean and Proterozoic supracrustal rocks in the Otter and Ducker lakes area, southern District of Keewatin, Northwest Territories: Current Research 1994-C Canadian Shield, Geological Survey of Canada, 165-174.

Bhatia, M.R., 1983, Plate tectonics and geochemical composition of sandstones: Journal of Geology, 91, 611-627.

Bhatia, M.R., Crook, K.A.W., 1986, Trace element characteristics of graywackes and tectonic setting discrimination of sedimentary basins: Contributions to Mineralogy and Petrology, 92, 181-193.

Cerca-Martínez, L.M., Aguirre-Díaz, G.J., Lopez-Martínez, M., 2000, The geologic evolution of the southern Sierra de Guanajuato, Mexico: A documented example of the transition from the Sierra Madre Occidental to the Mexican Volcanic Belt: International Geology Review, 42, 131-151.

Chaodong, W., Changsong, L., Yanping, S., Xue, E., 2005, Composition of sandstone and heavy mineral implies the provenance of Kuga Depression in Jurassic Tarin basin, China: Progress in Natural Science, 15, 633-640.

Crowell, J.C., 1955, Directional current structures from the prealpine flysch, Switzerland: Geological Society of America Bulletin, 66, 1351-1384.

Cullers, R.L., Barret, T., Carlson, R., Robinson, B., 1987, Rare earth element and mineralogical changes in Holocene soil and stream sediment: a case study in the wet mountains, Colorado, USA: Chemical Geology, 63(3), 275-295.

Cullers, R.L., Basu, A., Suttner, L.J., 1988, Geochemical signature of provenance in sand size material in soils and stream sediments near the Tobacco Root batholith, Montana, USA: Chemical Geology, 70(4), 335-348.

Dávila, A.V.M., Martínez, R.J., 1987, Una edad Cretácica para las rocas basales de la Sierra de Guanajuato, Universidad Nacional Autónoma de México, (abstract): Simposio sobre la geología de la región de Guanajuato, 19-20.

Dickinson, W.R., 1970, Interpreting detrital modes of graywacke and arkose: Journal of Sedimentary Petrology, 40, 695-707.

Dickinson, W.R., 1985, Interpreting provenance relation from detrital modes of sandstones, en Zuffa, G.G. (ed.), Provenance of arenites: NAIO ASI Series, C148, D, Reidel Publishing Company, Dordrecht 333-363.

Dickinson, W.R., Beard, L.S., Brakenridge, G.R., Erjavec, J.L., Ferguson, R.C., Inman, K.F., knepp, R.A., Lindberg, F.A., Ryberg, P.T., 1983, Provenance of North American Phanerozoic sandstones in relation to tectonic setting: Geological Society of America Bulletin, 94, $222-235$.
Echegoyen-Sánchez J., 1978, Yacimientos minerales de la Sierra de Arperos y Comanja Estado de Guanajuato: GEOMIMET (México), 93, 44-73.

Echegoyen-Sánchez, J., Romero-Martínez, S., Velázquez-Silva, S., 1970, Geología y yacimientos minerales de la parte central del distrito minero de Guanajuato: Consejo de Recursos Naturales No renovables, Boletín 75, México, D.F., 36 p.

Edwards, J.D., 1955, Studies of some early Tertiary red conglomerates of Central Mexico: U.S. Geology Survey Professional Paper, 264, 153-185.

Ferrari, L., López-Martinez, M., Aguirre-Díaz, G.J., Carrasco-Nuñez, G., 1999, Space-time patterns of Cenozoic arc volcanism in Central Mexico: From Sierra Madre Occidental to Mexican Volcanic Belt: Geology, 27(4), 303-306.

Ferrusquía-Villafranca, I., 1987, Reubicación geocronología del Conglomerado Guanajuato basada en nuevos mamíferos, in Programa, resúmenes y guía de excursión del simposio sobre la geología de la región de la sierra de Guanajuato, Guanajuato, Gto., 28-30 de abril: Universidad Nacional Autónoma de México, Instituto de Geología, 21-23.

Floyd, P.A., Leveridge, B.E., 1987, Tectonic environment of the Devonian Gramscatho basin, south Cornwall: Framework mode and geochemical evidence from turbidite sandstones: Journal of the Geological Society, 144(49), 531-542.

Folk, R.L., 1974, Petrology of Sedimentary Rocks: Austin, TX, Hemphill Press, second edition, $182 \mathrm{p}$.

Gazzi, P., 1966, Le Arenarie Del Flysch Sopracretaceo dell'Appennino Modenese: Correlazioni con il Flysch di Monghidoro: Mineralogica e Petrografica Acta, 12 69-97.

Guiza, R., 1949, Estudio geológico Del Distrito Minero de Guanajuato: Instituto Nacional para la Investigación de Recursos minerales, Boletín 22, 75 p.

Harms, J.C., 1969, Hydraulic significance of some sand ripples: Geological Society of America Bulletin, 80, 363-396.

Harms, J.C., 1979, Primary Sedimentary Structures: Annual Review of Earth and Planetary Sciences, 7, 227-248.

Hasenaka, T., Ban, M., Delgado-Granados, H., 1994, Contrasting volcanism in the Michoacán-Guanajuato volcanic field, Central Mexico: Shield volcanoes vs cinder cones: Geofísica Internacional, 33, 12-138.

Herron, M.M., 1988, Geochemical classification of terrigenous sands and shales from core and log data: Journal of Sedimentary Petrology, $58,820-829$.

Ingersoll, R.V., Bulard, T.F., Ford, R.L., Grimn, J.P., Pickle, J.P., Sares, S.W., 1984, The effect of grain size on detrital modes: a text of the Gazzi-Dickinson Point Counting method: Journal of Sedimentary Petrology, 54, 103-116.

Keshav Krishna, A., Rama Mohan, K., Murthy, N.N., 2011, A multivariate statistical approach for monitoring of heavy metals in sediments: A case study from Wailpalli Watershed, Nalgonda District, Andhra Pradesh, India: Research Journal of Environmental and Earth Sciences, 3(2), 103-113.

Kroonenberg, S.B., 1994, Effects of provenance, sorting and weathering on the geochemistry of fluvial sands from different tectonic and climatic environments: Proceedings of the 29th International Geological Congress, Part A, 69-81.

Lapierre, H., Ortíz, L.E., Abouchami, W., Monod, O., Coulon, C., Zimmermann, J.L., 1992, A crustal section of an intra-oceanic island arc: the Late Jurassic-Early Cretaceous Guanajuato magmatic sequence, Central México: Earth and Planetary Science Letters, $108,61-77$.

Martini, M., Mori, L., Solari, L., Centeno-García, E., 2011, Sandstone provenance of the Arperos Basin (Sierra de Guanajuato, Central Mexico): Late Jurassic-Early Cretaceous back-arc spreading as the foundation of the Guerrero terrane: The Journal of Geology, 119, 597-617.

McBride, E., 1962, Flysch and associated beds of the Martinsburg Formation (Ordovician), central Appalachians: Journal of Sedimentary Petrology, 32, 39-91. 
McLennan, S.M., 1989, Rare earth elements in sedimentary rocks: influence of provenance and sedimentary processes: Reviews in Mineralogy and Geochemistry, 24, 169-200.

McLennan, S.M., Nance, W.B., Taylor, S.R., 1980, Rare earth elementthorium correlations in sedimentary rocks, and the compositions of the continental crust: Geochemica et Cosmochemica Acta, 44, 1833-1839.

McLennan, S.M., and Taylor, S.R., 1991, Sedimentary rocks and crustal evolution: tectonic setting and secular trends: Journal of Geology, 99, 1-21.

McLennan, S.M., Hemming, S., McDaniel, D.K., Hanson, G.N., 1993, Geochemical approaches to sedimentation, provenance, and tectonics, en Johnson, M.J., Basu, A. (eds.), Processes controlling the Composition of Clastic Sediments: Boulder, Colorado, Geological Society of America Special Paper 284, 21-40. Monroy, L., 1888, Las minas de Guanajuato: Anales del Ministerio de Fomento de la República Mexicana, Tomo 10, México, D.F., 738 p.

Morton, A.C., 1985, A new approach to provenance Studies. Electron microprobe analysis of detrital garnets from middle Jurassic sandstones of the northern North Sea: Sedimentology, 32, 553-566.

Nieto-Samaniego, A.F., García-Dobarganes, B.J.A., Aguirre-Maese, A.L., 1992, Interpretación estructural de los rasgos geomorfológicos principales de la Sierra de Guanajuato: Revista del Instituto de Geología, Universidad Nacional Autónoma de México, 10, 1-5.

Núñez-Gonzalez, F., Martín-Vide, J.P., 2010, Downstream-migrating antidunes in sand, gravel and sand-gravel mixtures: River Flow 2010,1, 393-400.

Orozco, R., 1921, La Industria Minera de México. Distrito de Guanajuato. Secretaria de Industria, Comercio y Trabajo. Editor Departamento de exploraciones y Estudios geológicos, México, 163 p.

Ortíz-Hernández, L.E., Chiodi, M., Lapierre, H., Monod, O., Calvet, P., 1992, El arco intraoceánico alóctono (Cretácico Inferior) de Guanajuato. Características petrográficas, geoquímicas, estructurales e isotópicas del complejo filoniano y de las lavas basálticas asociadas, implicaciones geodinámicas: Revista del Instituto de Geología, Universidad Nacional Autónoma de México, 9 (2): 126-145.

Pettijohn, F.J., Potter, P.E., Siever, R., 1972, Sands and sandstones: New York, Springer-Verlag, $618 \mathrm{p}$.

Picard, M.D., High, L.R., 1973, Developments in Sedimentology. Sedimentary structures of ephemeral streams: Amsterdam, Elsevier, 223 p.

Puy-Alquiza, M.J., Miranda-Avilés, R., Salazar-Hernández, C., VegaGonzález, M., Cervantes, J., 2013, Characterization petrophysical of the Losero Formation in the Historical Architecture of the Guanajuato City, Mexico: Ingeniería Investigación y Tecnología, 14(2), 191-205

Randall, J.A., Saldaña, A.E., Clark, K.F., 1994, Exploration in a volcanoplutonic center at Guanajuato, Mexico: Economy Geology, 89, 1722-1751.

Ricci-Lucchi, F., 1995, Sedimentographica: Photographic atlas of sedimentary structures: U.S.A., Columbia University Press, 251 p.

Ronov, A.B., Balashov, Y.A., Girin, Y.P., Bratishko, R.K.H., Kazakov,
G.A., 1974, Regularities of rare earth element distribution in the sedimentary shell and in the crust of the earth: Sedimentology, 21, 171-193.

Roser, B.P., Korsch, R.J., 1986, Determination of tectonic setting of sandstone-mudstone suites using $\mathrm{SiO}_{2}$ content and $\mathrm{K}_{2} \mathrm{O} / \mathrm{Na}_{2} \mathrm{O}$ ratio: Journal Geology, 94, 635-650.

Roser, B.P., korsch, R.J., 1988, Provenance signatures of sandstone-mud stone suites determined using discriminant function analysis of major-element data: Chemical Geology, 67, 119-139.

Schulze, G., 1953, Observaciones geológicas y petrogénicas en el mineral de Guanajuato, con referencia especial al Losero: Mexico, Servicio Geológico Mexicano, Reporte Técnico, Archivo técnico 110019-5, $23 \mathrm{p}$

Tanner, W.F., 1967, Ripple marks indices and their uses: Sedimentology, 9, 89-104.

Tanner, W.F., 1971, Numerical estimates of ancient waves, water depth and fetch: Sedimentology, 16, 71-88.

Tardy, M., Lapierre, H., Bourdier, J.L., Coulon,C., Ortíz-Hernández, L.E., Yta, M., 1992, Intraoceanic setting of the western Mexico Guerrero Terrane- implications for the Pacific Tethys geodynamic relationships during the Cretaceous: Revista del Instituto de Geología, Universidad Nacional Autónoma de México, 10(2), 118-128.

Tardy, M.,Lapierre, H., Freydier,C., Coulon,C., Gill, J.B., Mercier de Lepinay, B., Beck, C., Martínez-Reyes, J., Talavera-Mendoza, O., Ortíz-Hernández, L.E., Stein, G., Boudier, J.L., Yta, M., 1994, The Guerrero suspect terrane (western Mexico) and coeval arc terranes (The Greater Antilles and the western Cordillera of Colombia): a late Mesozoic intraoceanic arc accreted to cratonal America during the cretaceous: Tectonophysics 230, 49-73.

Taylor, S.R., McLennan, S.M., 1985, The Continental Crust; Its composition and evolution: London, Blackwell, $320 \mathrm{p}$.

Valdéz-Moreno, G., Aguirre-Díaz, G.J., López-Martínez, M., 1999, El volcán La Jolla, estados de Querétaro y Guanajuato. Un Estratovolcán antiguo del Cinturón Volcánico Mexicano: Revista Mexicana de Ciencias Geológicas, 15, 181-197.

Wronkiewicz, D.J., Condie, K.C., 1987, Geochemistry of Archean shales from the Witwatersrand Supergroup, South Africa: source -area weathering and provenance: Geochimica et Cosmochimica Acta, 51, 2401-2416.

Wronkiewicz, D.J., Condie, K.C., 1990, Geochemistry and mineralogy of sediments from the Ventersdorp and Transvaal Supergroups, South Africa: Cratonic evolution during the Early Proterozoic. Geochimica et Cosmochimica Acta, 54, 343-354.

Zuffa, G.G., 1987, Unravelling hinterland and offshore paleogeography from deep-water arenites, en Leggett, J.K., Zuffa, G.G. (ed.), Marine clastic sedimentology: Concepts and case studies: London, Graham \& Trotman, 39-61.

Manuscript received: September 22, 2013.

Corrected manuscript received: December 31, 2013.

Manuscript accepted: January 8, 2014 